\title{
A CONDIÇÃO NOS DIREITOS PORTUGUÊS E NORTE-AMERICANO. POSSIBILIDADE E IMPOSSIBILIDADE*
}

\author{
LURDES VARGAS**
}

SumÁRIO: I Introdução. 1. Delimitação positiva do objeto da comparação. 2. Delimitação negativa do objeto da comparação. II Análise comparativa. Direito Norte Americano. 1. Delimitação da figura. 2. Modalidades relevantes. 3. Função e natureza. 4. Possibilidade e impossibilidade. Direito Português. 1. Delimitação da figura. 2. Modalidades relevantes. 3. Função e natureza. 4. Possibilidade e impossibilidade. III Síntese Comparativa. 1. Delimitação da figura e modalidades. 2. Função e natureza. 3. Possibilidade e impossibilidade originária. 4. Impossibilidade superveniente. 5. Nota final.

Resumo: O presente estudo desenvolve uma análise comparativa dos direitos português e norte-americano, procurando averiguar se nestes dois ordenamentos será admissível introduzir num contrato uma cláusula que faça condicionar todos ou parte dos efeitos desse contrato à ocorrência de um evento futuro e incerto. Concluindo-se que ambos os ordenamentos jurídicos em comparação oferecem essa solução, outras questões são colocadas: Se tal evento condicionante for desde o início impossível ou se tornar impossível, que sucede à cláusula e ao contrato? Há um regime especial aplicável a estes problemas? Que soluções oferece?

No final do estudo, concluiu-se que a condição norte-americana se adapta a casos muito diferentes e o seu regime também. Embora imprecisa nos limites, tem um regime de não verificação e impossibilidade da condição bastante completo, oferecendo soluções de muito bom senso. $\mathrm{O}$ regime jurídico português da condição é mais preciso, aparentemente mais claro e os contornos da condição são também mais precisos. Mas o regime jurídico da impossibilidade da condição é mais rígido e perante os casos concretos nem sempre oferece uma resposta clara e justa.

Palavras-Chave: Condição; Direito Comparado; Direito Norte-Americano; Direito Português; Impossibilidade Originária; Impossibilidade Superveniente.

\footnotetext{
* Este estudo é dedicado ao Professor Doutor Carlos Ferreira de Almeida, a quem agradeço a amizade e o ensino, e que exerceu, e exerce, uma profunda influência no meu percurso académico.

** Professora da Faculdade de Direito da Universidade Lusófona (Lisboa). Investigadora do CEAD — Centro de Estudos Avançados em Direito Francisco Suárez.
} 
Abstract: The present study develops a comparative analysis of the Portuguese and North American rights, seeking to determine whether it is admissible to introduce in a contract a clause that will condition all or part of the effects of that contract to the occurrence of a future and uncertain event. The conclusion being that both legal systems in this comparison offer such a solution, other questions are raised: If such a conditioning event is originally impossible or superveningly impossible, what happens to the clause and the contract? Is there a special regime that applies to these problems? What solutions does it offer?

At the end of the study, it was it was found that the North American condition adapts to very different cases and so does its regime. Although imprecise in its limits, it has a regime of non-fulfillment and impossibility of the condition quite complete, offering very common-sense solutions. The Portuguese legal regime of the condition is more precise, apparently clearer, and the contours of the condition are also more precise. But the legal regime of impossibility of the condition is more rigid and when faced with concrete cases it does not always offer a clear and fair answer

KeYwords: Condition; Comparative Law; North American Law; Portuguese Law; Original Impossibility; Supervening Impossibility. 


\section{I - INTRODUÇÃo}

\section{Delimitação positiva do Objeto da Comparação}

É possível (admissível) que um contrato contenha uma cláusula que faça depender todos ou parte dos seus efeitos da ocorrência de um evento futuro e incerto? E se o evento condicionante for desde o início impossível ou se tornar impossível, que sucede à cláusula e ao contrato? Há um regime especial aplicável a estes problemas? Que soluções oferece?

Estas questões delimitam o âmbito da comparação que se segue. A própria formulação dessas questões já pressupõe algumas respostas, numa tarefa de vai e vem. Parte-se de um pré-conhecimento de um regime jurídico, o português, e de uma preliminar pesquisa de um paralelo no ordenamento jurídico norte-americano. Em Portugal, o regime da condição; nos Estados Unidos, o regime da condition.

Depois da visita de reconhecimento aos regimes-base dos dois ordenamentos, concluiu-se que entre essas duas figuras há um paralelismo que ultrapassa a coincidência de denominação. E que relativamente a ambas é tratado o problema da possibilidade-impossibilidade.

Então, regressou-se ao direito português, tomou-se a noção de condição nele consagrada e ampliou-se (será?) essa noção, de modo a que ela possa compreender tanto as cláusulas que afetam produção de todos os efeitos de um contrato, como aquelas que afetam apenas parte dos efeitos. E o resultado foi a noção incorporada na primeira questão supra enunciada (a itálico). E acrescentou-se-lhe ainda o requisito da formulação hipotética. Ou seja, o evento deve ser previsto de forma estritamente hipotética e a sua ocorrência não deve corresponder a um dever das partes.

Em novo olhar para o direito norte-americano, verificou-se que, desse lado, a noção-construída também não encaixa perfeitamente - condition, em sentido técnico, pode ser algo mais amplo. Mas a noção-construída abrange um núcleo importante da condition.

E assim se tomou por assente como objeto da comparação um tertium genus: cláusula contratual que faça depender todos ou parte dos efeitos de um contrato da ocorrência de um evento futuro e incerto, sem constituir um dever. 


\section{LURDES VARGAS}

$\mathrm{Na}$ comparação procura-se identificar o seu regime geral — saber em que termos se admite a figura e como é tratada - e em particular analisar o regime da possibilidade-impossibilidade.

\section{Delimitação negativa do objeto da Comparação}

Excluídas, à partida, já estão as condições de fonte legal, incluindo as cláusulas contratuais que se limitem a transcrever condições que já integram um tipo ou subtipos contratuais. Excluem-se também as cláusulas que integrem negócios jurídicos unilaterais, restringindo-se a comparação às cláusulas dos contratos. Excluem-se as cláusulas inseridas em contratos constitutivos de garantias. E, em razão da matéria, excluem-se as cláusulas inseridas em contratos familiares, sucessórios, trusts e laborais.

Esta delimitação do objeto da comparação tem uma dupla finalidade: conter a comparação numa dimensão abarcável no tempo e na natureza do trabalho a empreender; assegurar uma certa coesão científica ao tema.

\section{II - Análise Comparativa}

Inicialmente estruturou-se a comparação tratando tema a tema do eixo sintagmático, recortando-se depois cada tema em duas partes, correspondentes aos ordenamentos norte-americano e português, que compõem o eixo paradigmático. Essa solução, que tem a aparente vantagem de facilitar o próprio raciocínio comparativo, revelou-se desvantajosa no caso. A natureza algo abstrata do objeto da comparação e, sobretudo no direito norte-americano, o esbatimento dos contornos da figura, reclamam que ela se apresente melhor em bloco, ordem jurídica a ordem jurídica, e em cada ordem jurídica tema a tema. Esta solução permite também que alguns elementos do eixo sintagmático (subtemas de comparação) não sejam exatamente iguais em cada ordem jurídica. O que se tornou necessário, ou pelo menos vantajoso, em face da diferente estrutura dos próprios regimes em cada ordenamento. 


\section{DIREITO NorTE-AMERICANO}

\section{Delimitação da figura}

\subsection{Aproximação ao Conceito}

No contexto do ordenamento jurídico norte-americano, condition pode ter vários sentidos. Todos corretos. Pode significar qualquer cláusula ou estipulação de fonte contratual: term, provision ou clause ${ }^{1}$, especialmente se inserida na expressão "terms and conditions", tão comum nos contratos ${ }^{2}$. Pode significar o evento que limita ou qualifica a transferência de propriedade (é este, por exemplo, o sentido que tem no direito dos trusts) ${ }^{3}$.

Noutro sentido, condition: "an event, the occurrence or non-occurrence of which gives rise to or extinguishes a duty." ${ }^{4} \mathrm{Ou}$ também, muito próximo,

"Significa um determinado facto operativo, posterior à aceitação e anterior à extinção do contrato, um facto do qual os direitos e deveres das partes dependem. (...) Esse facto (operativo) pode ser um ato de uma das duas partes contratantes, um ato de um terceiro, ou qualquer outro facto do nosso mundo físico. Pode ser uma prestação que se prometeu ou um facto relativamente ao qual não há promessa."

As duas últimas são definições mais técnicas, que agregam eventos com uma funcionalidade própria, com um âmbito que se aproxima daquele que se

1 Arthur Corbin, "Conditions in the Law of Contracts", Yale Law Journal, 28 (1918-1919): 743. Disponível in Faculty Scholarship Series, paper 2851, http://digitalcommons.law.yale.edu/fss papers/2851.

2 Samuel Williston, Williston on Contracts, vol. 13, ed. Richard A. Lord, 4. ${ }^{a}$ edição (St. Paul, Minnesota: West Group, 2000), 377.

3 American Law Institute, Restatement of the Law on Contracts (Second), Student Edition, 3. reimpressão (1.a: 1981) (St. Paul, Minnesota: American Law Institute Pub., 1990), anotação ao $\$ 224$, comm. a.

4 Claude D. Rohwer e Anthony M. Skrocki, Contracts - in a nutshell, $8^{2}$ edição (St. Paul, Minnesota: West Group, 2016), 376.

5 Williston on Contracts, vol. 13, 377. A tradução é minha, assim como todas as traduções doravante. Traduzirei as frases cujo sentido técnico não tema desvirtuar. Manterei na língua original pequenos excertos do texto sempre que entenda terem um sentido técnico muito próprio que a tradução possa desvirtuar. 
delineou para este trabalho. A última procura afastar a condição de existência ou formação do contrato (condition to the formation of a contract), que também existe no direito norte-americano e que a jurisprudência e a doutrina norte-americanas distinguem perfeitamente da condição de produção dos efeitos do contrato (condition to performance) $)^{6}$ - aquela que interessa aqui tratar.

Em Omaha Public Power District v. The Employers' Fire Insurance Co. ${ }^{7}$, o tribunal refere a necessária distinção entre condição da formação ou existência do contrato e condição de produção de efeitos ${ }^{8}$.

O Restatement on Contracts 2 nd, $\$ 224$, optou por restringir ainda mais o âmbito da condition: "condition is an event, not certain to occur, which must occur, unless its non-ocurrence is excused, before performance under a contract becomes due."

Em primeiro lugar, restringiu a palavra condition ao evento e afastou mesmo a cláusula (term) que se lhe refira. Depois, exige uma ligação a um contrato afastando todos os eventos ligados a outras figuras jurídicas. Exige também que o evento seja incerto.

Finalmente, o $\$ 224$ refere-se a um evento do qual o início da produção dos efeitos das obrigações das partes depende. Afastou-se assim do seu âmbito a anteriormente designada condition subsequent, de efeitos extintivos, agora consagrada no $\$ 230$.

A condition subsequent é agora enigmaticamente designada de event that terminates a duty, definida como "an event (that) is to terminate an obligor's duty of immediate performance or one to pay damages for breach”. O $\$ 230$ é extremamente lacónico. O evento é descrito pelos efeitos e pelo momento em que ocorre e não pela sua estrutura.

6 Ibidem, 375-378.

7327 F.2d 912 (1964), p. 915 . Salientando a distinção, cf. City of Houston v. West, 563 S.W.2d 680 (1978); Oppenheimer \& Co., Inc. v. Oppenheim, Appel, Dixon \& Co., 86 N.Y.2d 685 (1995). Neste último caso, a conclusão foi inversa, tratava-se da condição de formação do contrato.

8 “(...) a lei do Nebrasca é compatível com as definições reconhecidas que sustentam que uma condition precedent tanto pode ser uma condição que se deve verificar antes de o contrato se tornar vinculativo entre as partes, como uma condição que se deve verificar antes de surgir um dever de cumprir as obrigações de um contrato já existente." E, mais adiante, referindo-se à cláusula inserida pelas partes no contrato de empreitada (construction): "esta cláusula modificativa só pode ter uma interpretação. As partes quiseram que a vinculação ao cumprimento das suas obrigações ao abrigo do contrato existente ficasse dependente da ocorrência do evento descrito, um facto a preceder o cumprimento imediato, diferente de um mero lapso de tempo." 
A razão apontada para retirar o event that terminates a duty do conceito de condition é evitar a confusão entre as duas figuras que a designação comum causava9. Em todo o caso, a doutrina norte-americana pós-Restatement 2 nd continua a tratar a figura descrita no $\$ 230 \mathrm{em}$ tema de condição, designando-a de condition subsequent ${ }^{10}$, e as decisões judiciais referem-se-lhe como modalidade de condição.

Eventualmente, terá uma abrangência e finalidade que extravasa os contornos da figura definida como âmbito deste trabalho. Uma conclusão definitiva pressupõe o percurso de delimitação que se segue.

Para efeitos deste trabalho, quando se referir condição ou condition, tanto poderei referir-me ao evento do $\$ 224$, como à cláusula contratual que lhe respeita, tal como sucede na doutrina norte-americana na matéria. E poderei referir-me ao evento abrangido pelo $\$ 230$, usando a expressão condition subsequent ou event that terminates a duty, assim como poderei usar a primeira das duas para me referir à cláusula contratual que se refere ao evento.

\subsection{ORIGEM}

A cláusula que contiver uma condição com o sentido delimitado no $\$ 224$ do Restatement pode resultar do acordo das partes ou de decisão judicial. $\mathrm{Na}$ primeira hipótese, a condição (agora no sentido de cláusula) pode ser expressamente inserida pelas partes na redação do contrato (express condition) ou ser apurada pelo tribunal no seu trabalho interpretativo do contrato (implied in fact condition), apesar de não estar expressa no documento escrito (no caso de contrato escrito) ou nas declarações verbais das partes (no caso de contrato verbal). Na segunda hipótese, o próprio tribunal constrói uma condição e considera-a parte do contrato - apesar de a mesma

9 Nota Introdutória ao Tópico 5 do Restatement 2 nd - pp. 159-160. Ainda sobre a confusão inerente ao termo condition subsequent. cf. Restatement $2 n d, \$ 224$, Reporter's Note; Bertram Harneth e John V. Thorton, "The Insurance Condition Subsequent: A Needle in a Semantic Haystack", Fordham Law Review, 17 (1948): 220 ss. Disponível em: http://ir.lawnet.fordham.edu/fr/vol17/iss2/3.

10 Claude D. Rohwer e Anthony M. Skrocki, Contracts..., 405 ss; E. Allan Farnsworth, Farnsworth on Contracts, vol. II, 2. ${ }^{a}$ edição (New York: Aspen Pub., 1998), 397 ss.; Joseph M. Perillo, Calamari and Perillo on Contracts, 5. ${ }^{a}$ edição, 1. ${ }^{a}$ reimpressão (St. Paul, Minnesota: Thompson/ West Group, 2004), 416 ss.; Williston on Contracts, vol. 13, 408 ss. 


\section{LURDES VARGAS}

não se poder inferir, nem expressa, nem implicitamente, do contrato porque o tribunal entende que é essencial para regular os direitos e deveres das partes numa perspetiva de razoabilidade (constructive condition ou implied in law condition) (\$226).

Afasta-se do âmbito do $\$ 224$ qualquer estipulação com idêntica função mas de fonte legal.

As condições de fonte contratual (expressas ou implícitas, mas muitas vezes ambas designadas genericamente de expressas/ express) nem sempre são fáceis de reconhecer. O uso de expressões tais como on condition that, provided that, in the event that $\mathrm{e}$ if são frequentes e são normalmente esclarecedoras $^{11}$. Mas pode não suceder assim. O reconhecimento e obtenção do sentido de uma condição pode não ser óbvio, mas resultar do processo normal de interpretação do contrato de acordo com os princípios aplicáveis a essa tarefa e com uso dos elementos que lhe são próprios. Assim, será dado elevado peso à intenção das partes (\$202 (1)) e na escolha do sentido razoável é geralmente dada prevalência ao sentido que é contra os interesses da parte que redigiu o contrato (\$206).

Quanto às constructive conditions, são uma produção judicial — algo próximo de uma função de integração do contrato —, justificadas por imperativos de justiça e de equilíbrio do contrato e não por uma tentativa de reconstrução da intenção das partes ${ }^{12}$. Normalmente, uma constructive condition refere-se a um dever de realizar uma prestação, o qual assumirá a dupla categoria de dever e condição, perante um contraposto dever ou conjunto de deveres de prestar da contraparte contratual ${ }^{13}$. Ou seja, o tribunal toma o dever de uma das partes do contrato e transforma-o em condição do dever ou deveres de realizar a prestação da outra parte.

A distinção entre express e implied in fact conditions, por um lado, e constructive ou implied in law conditions, por outro, é de grande relevância. Enquanto as primeiras devem ser estrita e literalmente aplicadas pelo tribunal, as

11 Restatement 2nd, \$226, comment a; Farnsworth on Contracts, II, 394.

12 Arthur Corbin, Corbin on Contracts (one volume edition), 27ª reimpressão (1. impressão: 1952)

(St. Paul, Minnesota: West Group, 2001), 590-592; Claude D. Rohwer e Anthony M. Skrocki, Contracts..., 389.

13 Claude D. Rohwer e Anthony M. Skrocki, Contracts..., 386-389 
segundas bastam-se com uma aplicação em substância ou na essência ${ }^{14}$. O que é muito relevante para efeitos de apuramento da possibilidade e impossibilidade da condição. Por outro lado, por natureza, uma constructive condition é sempre a material part of the agreed exchange e uma express condition ou uma implied in fact condition podem ser ou não - o que também é relevante para os regimes da não verificação e da impossibilidade superveniente da condição (\$\$229 e 271).

Já a chamada condition subsequent ou event that terminates a duty resulta necessariamente de fonte contratual, e do contrato original entre as partes $^{15}$.

\subsection{O EVENTO}

Para existir condição no sentido do $\$ 224$ é necessário que se trate de um evento incerto. Este é um requisito fundamental da condição segundo o Restatement $2 n d$, evidentemente correspondente a uma evolução na própria jurisprudência. Assim, não se inclui no conceito de condição um evento correspondente à mera passagem do tempo, visto que não é incerto. Mais, um evento, ainda que incerto, meramente indicado num contrato para medir a passagem do tempo após a qual o devedor deverá realizar a prestação também não é considerado uma verdadeira e própria condição, não se lhe aplicando os seus exatos efeitos ${ }^{16}$.

Já no que respeita à localização no tempo, o evento não necessita de ser objetivamente futuro relativamente ao momento de celebração do contrato. Pode tratar-se de um evento passado ou contemporâneo. $\mathrm{O}$ requisito de

14 Restatement 2nd, \$226, comment c; Calamari and Perillo on Contracts, 419 e 425; Claude D. Rohwer e Anthony M. Skrocki, Contracts..., 382, 389.

15 Arthur Corbin, "Discharge of Contracts", Yale Law Journal, 22 (1913): 527. Disponível in Faculty Scholarship Series, paper 2871, http://digitalcommons.law.yale.edu/fss_papers/2871.

16 Restatement 2nd, $\$ 224$, comment b ao mesmo parágrafo e $\$ 227$, comment b. Em Ewell v. Landing, 199 Md. 68, 85 A.2d 475 (1952), o tribunal considerou que a condição da obrigação de pagar uma determinada dívida quando o devedor vendesse uma certa propriedade era admissível. Porém, visto que o evento futuro foi apenas escolhido pelas partes para marcar o tempo conveniente para o pagamento, e visto que esse evento não ocorreu como esperado, então o direito infere uma promessa de pagar num prazo razoável. - p. 71. Também Calamari and Perillo on Contracts, 421-422; Farnsworth on Contracts, II, 413-417. 


\section{LURDES VARGAS}

incerteza obriga apenas que a ocorrência do evento seja desconhecida pelas partes, ou seja, subjetivamente futura. ${ }^{17}$

O evento incerto pode ser positivo ou negativo, no sentido de poder ser a ocorrência de algum facto ou a falha ou não-ocorrência de um facto ${ }^{18}$.

Relativamente à condition subsequent, tanto o Restatement $\$ 230$, como a jurisprudência e doutrina em geral, não impõem um requisito de incerteza. Antes pelo contrário, alguns dos escassos exemplos desta figura, que a própria doutrina norte-americana afirma ser rara, referem-se ao mero decurso do tempo após o vencimento ou o incumprimento ${ }^{19}$. Assim, desde já se conclui que a figura extravasa o âmbito da presente comparação. Ou seja, parte dos eventos abrangidos pelo $\$ 230$, e as cláusulas que lhes respeitam, estão fora do fenómeno a comparar.

\subsection{Abrangência}

Afastada a condição de formação ou existência do contrato ${ }^{20}$, a condição de produção dos efeitos do contrato, reportada ao $\$ 224$, normalmente refere-se a um ou alguns efeitos do contrato. Difícil é realmente encontrar casos ou exemplos de condição de produção de todos os efeitos do contrato. O conceito de condição está desenhado para os casos de afectação de parte dos efeitos de um negócio, normalmente, o/s dever/es de uma das partes. Até por causa da maneira como um contrato é construído: promise-acceptance.

Quase somos levados a crer que quando se pretende paralisar todos os efeitos de um contrato se recorre normalmente à condição de existência ou formação do contrato. Mas não necessariamente.

17 Restatement 2nd, \$224, comment b; Williston on Contracts, vol. 13, 367-373.

18 Restatement 2 nd, $\$ 224$, comment b.

19 Calamari and Perillo on Contracts, 416; Claude D. Rohwer e Anthony M. Skrocki, Contracts..., 405. Embora não necessariamente. Há exemplos, raros, de eventos qualificados como condition subsequent de natureza incerta: Calamari and Perillo on Contracts, 417-418.

20 Efeitos totais têm as condições de formação ou existência do contrato. Cf. Williston on Contracts, vol. 13, 375-376 e casos da nota 28. 
Em National Products Company, Inc. v. Atlas Financial Corp. ${ }^{21}$, encontrava-se sob apreciação uma condition precedent aposta num contrato de empréstimo. $\mathrm{O}$ tribunal concluiu que o contrato se formou, mas que qualquer dever da Atlas só se tornaria absoluto com a verificação das condições, correspondentes ao fornecimento de documentação pelo financiado, uma certificação de arquiteto e a disponibilização das instalações para inspeção. Todos os deveres da Atlas estavam sujeitos a estas condições. E, subentende-se, também nenhum dever resultaria para a financiada 215 Broad Corp. enquanto as condições não se verificassem ${ }^{22}$.

De qualquer dos modos, para efeitos de regime da condition (precedent) é indiferente se a condição de produção dos efeitos é total ou parcial. Só será relevante se, e na medida em que, a afetação de parte dos efeitos do contrato se reflita em ser a material part of the agreed exchange ou não ( $\$ \$ 229$ e 271).

A condition subsequent ou event that terminates a duty, pelo contrário, tem normalmente uma abrangência total, respeita a todo o contrato, a todas as obrigações das partes.

\subsection{FormulaÇão}

Com um olhar proveniente de um sistema de direito civil as figuras jurídicas do common law parecem muitas vezes desprovidas de rigor, de contornos demasiado incertos. Porém, num segundo olhar, pode ser reconhecida uma unidade justificada pela mesma função (uma função que noutro ordenamento jurídico poderia ser desempenhada por várias figuras jurídicas de classes diferentes).

A condição no sentido do $\$ 224$ do Restatement abrange eventos que integram cláusulas com uma formulação ou estrutura muito diferente. Se a condição é expressa, ela normalmente exprime-se numa clara formulação hipotética (se, na condição de, sujeito a). Mas a condição implícita (implied in

21238 Pa.Super. 152, 364 A.2d 730 (1976).

22 Também Lach v. Cahill et al., 138 Conn. 418, 85 A.2d 481 (1951) se refere a uma condição de produção dos efeitos de todo o contrato relativo à futura compra e venda de um imóvel - embora, a linguagem usada em algumas partes da decisão seja ambígua, pendendo para a condição de formação do contrato. 


\section{LURDES VARGAS}

fact) e a condição de fonte judicial (constructive) já podem ter uma formulação completamente diferente - mesmo já como resultado do trabalho interpretativo ou integrativo.

Este é um aspeto crítico. A condição do $\$ 224$ não é dever, é distinta de dever, mas pode coincidir com um dever. O \$225 (3) é bastante claro: “A não ocorrência de uma condição não é um incumprimento de uma parte, a não ser que esta tenha o dever de assegurar a ocorrência da condição." O comentário ainda é mais esclarecedor:

"Quando uma parte escolhe usar a instituição contrato para induzir a outra parte a causar a ocorrência de um evento, ela pode obtê-lo fazendo o evento uma condição do seu próprio dever (...). Ou pode fazê-lo conseguindo que a outra parte assuma o dever da ocorrência do evento. Ou pode fazer ambos."23

A terceira opção significa que o dever de realizar a prestação de uma das partes fica dependente do cumprimento do dever da outra parte. Este resultado é obtido através da formulação de uma condição partindo de um dever ${ }^{24}$. E também pode suceder que uma condição, inicialmente formulada pelas partes como simples condição, possa assumir a dupla natureza de dever-condição como resultado de construção judicial25.

Note-se que esta modalidade não se confunde com a eventual constituição (de fonte judicial) de um dever acessório, a recair sobre uma das partes do contrato, de desenvolver todos os esforços razoáveis para que uma condição se realize ${ }^{26}$. Neste caso não há um dever de resultado. Enquanto na condição-dever há um dever de resultado.

23 Restatement 2 nd, $\$ 225$, comment d. Também, Farnsworth on Contracts, II, 405-407.

24 No common law, o próprio regime da order of performance é construído com base na figura da condição. Cf. Restatement $2 n d$, $\$ \$ 234$ e 237, incluindo comentário a. Para uma perspectiva comparativa, James Crawford e Simon Olleson, “The Exception of Non-performance: Links between the Law of Treaties and the Law of State Responsibility", Australian Year Book of International Law, vol. 21 (2000): 55-74 (também in www.lcil.cam.ac.uk). Inclui uma referência ao leading case Kingston v. Preston, Lofft 194 (1773) (p. 17 do paper online).

\section{Restatement 2 nd, $\$ 225$, comment d.}

26 Restatement 2nd, $\$ 225$, illustration 8, e Lach v. Cabill et al., 138 Conn. 418, 85 A.2d 481 (1951), onde o tribunal decidiu que: "A condição do contrato implicava uma promessa do autor no sentido de desenvolver os esforços razoáveis para obter um empréstimo (mortgage) adequado."- p. 422. A condição da obrigação de compra de uma casa correspondia à obtenção do empréstimo. 
Sempre que a condição também é dever, ou o dever também é condição, é discutível falar de formulação hipotética. Porque a condição não é uma mera hipótese, é um imperativo. Mas, num certo sentido, essa formulação existe: "O A deve realizar a sua prestação, um transporte, na sua próxima viagem marítima; B obriga-se a realizar a sua contraprestação se A realizar a sua como estipulado." E só se existir este tipo de formulação é que o dever é condição nos termos do $\$ 224$ e com o seu regime próprio.

Saber se há ou não uma condição, se um dever é ou não uma condição são problemas de interpretação de alguma dificuldade ${ }^{27}$. Alguns princípios podem ajudar. Estando em dúvida se um evento é condição, é preferida uma interpretação que reduza o risco de prejuízo injustificado ou sem causa (forfeiture), a não ser que o evento esteja sob controlo do credor ou este tenha assumido o respetivo risco; prefere-se concluir que a ocorrência de um evento é um dever para o credor a concluir-se pela existência de uma condição - a não ser que o contrato seja de um tipo em que normalmente resulte deveres apenas para uma das partes ou caso o evento não esteja sob controlo do credor; prefere-se concluir pela existência de uma condição do cumprimento (precedent) a concluir que a não ocorrência do evento é uma causa de extinção do dever de realizar a prestação (condition subsequent) (\$227).

A condição-dever está fora do âmbito da presente comparação. Não se abordará ou discutirá por si. Pode suceder, porém, que alguns casos paradigmáticos do regime da condição, necessários para ilustrar outros aspetos do seu regime, sejam de condição-dever. Nesse caso poderão ser citados na estrita necessária medida.

Já a cláusula referente ao evento abrangido pelo $\$ 230$ implica uma formulação necessariamente hipotética. Neste caso, pela natureza dos efeitos, condição não pode coincidir com dever.

27 Restatement 2nd, \$225, illustrations 6 e 7; Farnsworth on Contracts, II, 407 ss. Em Lach v. Cahill et al. (cit.) o tribunal distingue condição de promessa: "Uma condição é distinta de uma promessa na medida em que não cria nenhum direito ou dever, em si ou de si própria, sendo meramente um fator limitativo ou modificativo." -421. 


\section{Modalidades Relevantes}

\subsection{QuANTO AO MOMENTO DE AFETAÇÃo}

Numa primeira leitura tudo parecia simples: condition precedent seria uma condição início da produção dos efeitos; e condition subsequent uma condição de extinção dos efeitos. Enquanto a condition precedent é necessariamente um evento incerto; a condition subsequent em si pode corresponder a um evento certo ${ }^{28}$. Mas a distinção é mais complicada do que isso.

O Restatement 2nd tentou separar as duas figuras - $\$ 224$ e $230-$ precisamente porque, à partida muito diferentes do ponto de vista funcional, podem facilmente confundir-se. Esta opção pretende refletir uma evolução da própria jurisprudência, do common law, e tem expressão na doutrina atual nesta matéria.

A distinção entre condition precedent e condition subsequent não tem como critério essencial, pelo menos exclusivo, o tipo de efeitos operados, mas antes o momento de ocorrência do evento-condição ${ }^{29}$. Há condition precedent quando o evento opera antes do vencimento de uma obrigação de realizar a prestação (antes do incumprimento); há condition subsequent quando o evento opera depois do vencimento de uma obrigação de realizar a prestação ${ }^{30}$ (eventualmente, depois do incumprimento). Em Northwestern Nat. Life Ins. Co. v. Ward, um caso de 1915, reportado ao Restatement 1st, já encontramos esse critério distintivo ${ }^{31}$, assim como em Graves v. Tru-Link Fence Co., já pós-Restatement $2 \mathrm{nd}^{32}$.

28 Restatement 2 nd, $\$ 230$, incluindo comentários: nenhuma referência à incerteza.

29 Corbin on Contracts, 696 ss; Arthur Corbin, "Discharge of Contracts", 523.

30 Restatement 2 2nd, $\$ 230$ (1).

3156 Okla. 188, 155 P. 524 (1915): "A condition precedent de um contrato é aquela que reclama a prática de um ato ou a ocorrência de um evento depois de o contrato ter sido celebrado, e de cuja prática ou ocorrência dependem as obrigações desse contrato. A condition subsequent de um contrato é aquela que segue a execução do contrato e opera a sua inviabilização ou anulação, mediante a subsequente falha de qualquer das partes em assegurar a condição". A linguagem está perigosamente invertida: considera-se "falha em assegurar a condição" o que na verdade é falha em impedir que a condição resolutiva se verifique.

32905 F.Supp. 515 (1995): "Uma condition precedent é um evento que deve ocorrer ou um ato que uma das partes de um contrato existente deve praticar antes de ser exigível o cumprimento da outra 
Enquanto a condition precedent tem por efeito próprio a simples não produção dos efeitos do contrato condicionados (só há incumprimento se a condição também for um dever, como consequência desta segunda natureza); a ocorrência da subsequent determina a nulidade ou o equivalente do contrato - null and void. Tratando-se de um contrato, o efeito genericamente designado de discharge ${ }^{33}$ significa uma extinção definitiva dos efeitos do contrato e em princípio com efeitos retroativos ${ }^{34}$.

Mas por vezes as duas figuras confundem-se.

Assim, é considerado condition precedent: "Mother promises to pay son $\$ 2,000$ per month for the next three years provided that, if son drops out of school, mother's duty to pay will cease." ${ }^{35} \mathrm{O}$ motivo é que não há nenhum dever de cumprimento imediato antes de a condição de se manter na escola se verificar ${ }^{36}$.

Ou seja, sempre que haja um contrato de efeitos duradouros, de continuada execução, se o evento previsto com efeitos de dispensa do cumprimento não tiver de ocorrer depois do vencimento (e incumprimento) de cada uma das prestações acordadas, há condition precedent e não subsequent. Logo, perante um critério de distinção prevalecente cronológico, a condition precedent pode ter funções bastante diferentes: pode marcar o início da produção dos efeitos condicionados e pode também, de certo modo, extinguir efeitos condicionados, no sentido de eles só se produzirem enquanto o evento previsto se mantiver/ continuar a existir e deixarem de se produzir se esse evento cessar.

A verdadeira condition subsequent, ou evento do $\$ 230$, é rara. Em busca de uma verdadeira condition subsequent, quase sempre se encontram eventos correspondentes ao decurso do tempo após o incumprimento que extingue o

parte." (...); A condition subsequent é um evento que, se ocorrer, extingue a obrigação contratual pré-existente" -520 .

33 Restatement 2 nd, $\$ 230(1)$.

34 Williston on Contracts, vol. 13, 408-409. Para uma noção e explicação sintética de discharge no common law, cf. Black's Law Dictionary, 6. ${ }^{a}$ edição (St. Paul, Minnesota: West Pub., 1990), 463.

35 Claude D. Rohwer e Anthony M. Skrocki, Contracts..., 405.

36 Ibidem, 405. 


\section{LURDES VARGAS}

direito de ação ${ }^{37}$. Mais raramente, o evento correspondente à condition subsequent poderá ser incerto ${ }^{38} 39$.

A distinção formal entre as duas modalidades, difícil, até poderia ser inútil ou desnecessária. Mas não é. Desde logo em sede processual a distinção é muito relevante. Cabe ao credor o ónus da prova do seu crédito e da ocorrência da condition precedent; cabe ao devedor o ónus de provar a ocorrência de uma condition subsequent $t^{40}$. E, como adiante se verá, o regime da respetiva impossibilidade é substancialmente diferente.

\subsection{QUANTO À ORIGEM DO EVENTO}

No common law as figuras jurídicas são normalmente muito polivalentes. Isso passa-se precisamente com a condição. O evento do $\$ 224$ pode ter origem natural ou humana - de terceiro ou de uma das partes (credor ou devedor). O mesmo sucede com o abrangido pelo $\$ 230$.

O evento condicionante pode estar largamente sob controlo do próprio devedor - assim sucede no caso de o proprietário de uma casa se obrigar a pagar a pintura on the owner's honest satisfaction with the job; ou sob

37 Restatement 2nd, \$230, illustrations 1 e 2; Corbin on Contracts, 696; Calamari and Perillo on Contracts, 416; Claude D. Rohwer e Anthony M. Skrocki, Contracts..., 405-406; Farnsworth on Contracts, II, 397, nota 19.

38 Arthur Corbin, "Discharge of Contracts", 523 - no caso-exemplo apresentado o evento é o incumprimento de uma das partes que extingue o dever de cumprir da outra.

39 Em Northwestern National Life Ins. Co. v. Ward (já citado), constituía condition subsequent a seguinte estipulação: "Nenhum processo fundado na lei ou em equity, com um pedido baseado na presente apólice, poderá dar entrada decorrido um ano da data real da morte do segurado, e se tal processo for intentado depois desse período de um ano, o decurso do tempo será considerado extintivo desse processo, não obstante disposição legal em contrário." Em Burger King Corp. v. Family Dining, Inc. (426 F.Supp. 485) considerou-se condition subsequent um evento complexo incerto: "Se no final do ano um, dois, três, quatro, cinco, seis, sete, oito, nove ou dez, da presente data, ou em qualquer altura durante os próximos oitenta (80) anos, não houver o respetivo requisito mínimo de operações BURGER KING no ativo ou em construção ativa no "território exclusivo", ao abrigo das licenças da Companhia, este contrato cessará e deixará de ter qualquer força ou efeito." Note-se que este caso mostra como é difícil distinguir condição de dever e condition precedent de condition subsequent. Considerou-se tratar-se condition subsequent por envolver o efeito extintivo de um contrato, quando, de acordo com o critério definido no $\$ 230$ do Restatement 2 nd e na doutrina atual, talvez pudesse ser qualificada como condition precedent. Fico na dúvida se é relevante tratar-se de um caso pré-Restatement 2 nd.

40 Claude D. Rohwer e Anthony M. Skrocki, Contracts..., 406; Farnsworth on Contracts, II, 397 398. 
o controlo do credor - tal como quando a seguradora se compromete a indemnizar os danos emergentes de incêndio mediante prova dos danos, fornecida pelo segurado no prazo de 60 dias (neste caso, o requisito dessa conduta do segurado não foi formulado como um dever $)^{41}$. Um contrato pode ser condicionado à não ocorrência de greves, incêndios e causas além do controlo do devedor. E é considerada uma condition precedent ${ }^{42}$. Uma condição clássica corresponde à autorização, aprovação ou certificação de um ato por parte de um terceiro, nomeadamente certificação de arquiteto ou engenheiro em contrato de empreitada de construção ${ }^{43}$. Mas também há uma condição válida quando a realização de uma prestação fica sujeita a ordem do credor (on demand), assim como na promessa de realizar a prestação quando puder, ou quando tiver rendimentos ${ }^{44}$. E também na promessa de realização do pagamento sujeita a satisfação pessoal do promitente-devedor relativamente à contraprestação $0^{45}$.

Porém, a condição arbitrária é censurada. Quando a condição de um dever de realizar uma prestação corresponde à satisfação do devedor relativamente à prestação da contraparte, é preferida uma interpretação no sentido de se verificar a condição if such a reasonable person in the position of the obligor would be satisfied. ${ }^{46} \mathrm{Ou}$ seja, perante a falta de clareza ou excessiva abrangência da estipulação, não se pressupõe que o credor assumiu o risco da insatisfação irrazoável do devedor. Nesse caso, sempre que possível, aplica-se um teste objetivo de satisfação com base num critério de razoabilidade. Se o critério objetivo não for suscetível de ser aplicado no caso concreto, por pragmatismo, o tribunal aplicará um teste subjetivo de séria satisfação ${ }^{47}$. Em resumo, uma condição arbitrária pode ser aceite como válida, mas o seu sentido é ajustado pelo tribunal.

41 Exemplos em Farnsworth on Contracts, II, 393.

42 Corbin on Contracts, 608-609.

43 Ibidem, 616-618.

44 Ibidem, 608 e 609.

45 Ibidem, 610-616.

46 Restatement 2nd, \$228. Também, Farnsworth on Contracts, II, 418-419.

47 Restatement 2 nd, $\$ 228$, comment b. 


\section{LURDES VARGAS}

A condição absolutamente arbitrária, a que não seja possível aferir por qualquer critério de razoabilidade, é inaceitável. Nesse caso considera-se que não há uma verdadeira promessa, a promessa é ilusória. Se eu "prometo pagar se me apetecer” não há promessa, porque não há um benefício, uma contrapartida (consideration) que justifique uma outra promessa ${ }^{48}$.

\section{Função e natureza}

A jurisprudência e a doutrina norte-americanas não discutem a natureza da condição, no sentido de problematizar a sua essência e a sua relação com o contrato condicionado. $\mathrm{O}$ common law é pragmático. Não existe a necessidade latina de classificar e qualificar.

Quando se fala da natureza da condição, define-se condição e delimita-se condição ${ }^{49}$ nos termos que já referimos no ponto 1 . Mas, se procurarmos melhor, verificamos que a jurisprudência e a doutrina norte-americanas consideram a condição como um elemento qualificativo da promessa: "a condição não cria qualquer direito ou dever por si e é meramente um fator limitativo ou modificativo" 50 ; "uma condição contratual deve ser distinguida de uma promessa, obrigação ou estipulação, na medida em que uma condição não cria qualquer direito ou dever por si, mas apenas opera como uma estipulação contratual limitativa ou modificativa" ${ }^{51}$. Poder-se-á dizer que essa é a natureza da condição.

Já as finalidades da condição são apresentadas de forma muito clara na jurisprudência, Restatement e demais doutrina. Há um consenso. A condição serve para transferir para o credor o risco da sua não-ocorrência ou para induzir o credor a causar o evento ${ }^{52}$. A finalidade de transferência do risco

48 Restatement $2 n d, \$ 71$, comments a e b; Corbin on Contracts, 610; Calamari and Perillo on Contracts, 213-214;

49 Williston on Contracts, vol. 13, 365-370.

50 Lach v. Cabill, 138 Conn. 418, 85 A.2d 481 (1951). Também, Corbin on Contracts, 592-593; Williston on Contracts, vol. 13, 367 e 378.

51 Favell v. U.S., 16 Cl. Ct. 700, 1980 WL 40057 (1989).

52 Restatement 2 nd, $\$ 224$, comment b. Também, Farnsworth on Contracts, II, 395. 
pode existir, esteja o evento sob controlo do credor, de terceiro ou do próprio devedor. Já a segunda finalidade só se aplica aos eventos que se encontrem essencialmente sob controlo do credor. $\mathrm{E}$ ambas as finalidades podem ainda ser concentradas numa mais ampla: "as condições são inseridas para proteção do promitente" 53 .

\section{Possibilidade E IMPOSSIBILIDAde}

\subsection{IMPOSSIBILIDADE ORIGINÁRIA: CONCEITO E REGIME}

\section{A) Da condition precedent}

A possibilidade e a impossibilidade originária da condição é uma matéria não autonomizada. Não se encontra em tema de condição, mas antes a propósito da formação do contrato. Se a condition precedent não é um elemento autónomo ou separável da promessa, mas antes um elemento qualificativo da mesma, limitativo ou modificativo, é natural que as suas anomalias originárias sejam tratadas como defeitos ou vícios da própria promessa.

Tratando-se de um contrato bilateral (assim se chamando àquele do qual resultam obrigações para ambas as partes), para haver uma promessa válida esta tem que constituir um benefício suficiente ou uma contrapartida suficiente (consideration) para a parte contrária também prometer ${ }^{54}$. Uma promessa condicional não deixa de ser suficiente consideration por ser condicional. Mesmo que a promessa seja condicionada por um ato do próprio promitente ${ }^{55}$.

Mas se a condição de uma promessa, em contrato bilateral ou unilateral (assim se chamando àquele do qual só resultam obrigações para uma das partes), não for possível desde o início com o conhecimento de ambas as partes, não há qualquer promessa. As partes não quiseram contratar ${ }^{56}$.

53 National Products Co., Inc. v. Atlas Financial Corp., 238 Pa. Super. 152, 364 A.2d 730 (1975).

54 Calamari and Perillo on Contracts, 204-208.

55 Corbin on Contracts, 214-216.

56 Restatement 2 nd, $\$ 76$, incluindo comment b.. 


\section{LURDES VARGAS}

Se for impossível apenas com o conhecimento do promitente, há uma promessa, mas é uma illusory promise, e como tal void, sem nenhum efeito. Tratando-se de contrato unilateral, não há contrato. Tratando-se de contrato bilateral, a promessa condicional não servirá como consideration $(\$ 76)^{57}$. E nesse caso, em princípio, todo o contrato será void ${ }^{58}$. E não produzirá quaisquer efeitos, não obrigando as partes.

"A promete a B pagar-lhe $\$ 5.000$ se o navio de B que se encontra no mar se perder (definitivamente), sabendo que o navio não está perdido. A promessa de A é ilusória e não é considerada consideration para obter uma promessa em contrapartida." Inversamente: "A faz a mesma promessa não sabendo se o navio se perdeu ou não. A promessa de A é consideration mesmo que $\mathrm{A}$ tenha motivos para saber que o navio não se perdeu." ${ }^{.59}$

Crucial é o conhecimento da possibilidade da condição pelo próprio promitente.

Se ele sabe que a condição não é possível, embora o promissário o ignore, pode considerar-se que há uma promessa, mas esta, ilusória, não é suficiente consideration para obter uma promessa da outra parte. Mas se, no entender do promitente, o evento for improvável, mas possível, já há suficiente consideration $^{60}$. No direito norte-americano os eventos que acionam os efeitos principais dos contratos aleatórios têm a natureza de condição, sendo a promessa válida não obstante a elevada probabilidade de não ocorrência. Ou mesmo não obstante o evento já ter ocorrido e afinal ser objetivamente impossível. Assim sucede com a aposta e o seguro, por exemplo ${ }^{61}$.

Se o promitente genuinamente acredita que o evento é possível, mesmo que objetivamente esse evento nunca possa vir a ocorrer, a promessa constitui consideration.

\footnotetext{
57 Também, Restatement 2 nd, $\$ 76$, comment b, e $\$ 77$, comment a.

58 Calamari and Perillo on Contracts, 213-215.

59 Restatement 2 nd, $\$ 76$, ilustrations 1 e 2.

60 Corbin on Contracts, 216.

61 Ibidem, 217.
} 
Este regime é coerente com a tendência do common law de procurar salvar a promessa até ao limite. À condição subjetivamente possível, mas objetivamente impossível, aplicar-se-á depois o regime da não verificação da condição ou da impossibilidade superveniente da condição, que pode permitir ou não que a promessa se salve definitivamente.

No que respeita a distinções, nem a jurisprudência, nem a doutrina, se preocupam em distinguir a impossibilidade material da legal.

\section{B) Da condition subsequent}

Impossibilidade da condition subsequent, por seu lado, nem sequer é um problema. Ou pelo menos não é tratado como tal pela jurisprudência e pela doutrina. O seu regime é simplicíssimo. Se o evento não é possível desde o início, não há condition subsequent, e o dever torna-se absoluto, incondicionado ${ }^{62}$.

\subsection{IMPOSSIBILIDADE SUPERVENIENTE: CONCEITO E REGIME}

\section{A) Da condition precedent}

A impossibilidade da condition precedent desdobra-se em dois regimes diferentes: o regime da simples não verificação da condição ( $\$ \$ 225$ e 229) e o regime da impossibilidade da condição (\$271). Ou seja, distingue-se se a condição não aconteceu dentro de um curso normal dos acontecimentos e se não sucedeu porque realmente se tornou impossível por motivos externos.

\section{a) Simples não verificação}

A consequência normal da não verificação de uma condição é a suspensão do efeito ou efeitos do contrato condicionados. A obrigação condicionada não se vence enquanto a condição não se verificar $(\$ 225(1))^{63}$. E, por princípio, a não verificação da condição não é causa de qualquer sanção para a parte que tinha o controlo do evento. Apenas será se a condição também for um dever (\$225 (3)). Estes são os efeitos normais e primários da simples não verificação.

62 Arthur Corbin, "Conditions in the Law..., 756; Williston on Contracts, vol. 13, 408.

63 Arthur Corbin, "Conditions in the Law..., 751 - antes do Restatement 2 nd. 


\section{LURDES VARGAS}

Se a condição se considerar definitivamente não verificada, dá-se o segundo efeito: o devedor deve considerar-se dispensado do cumprimento (discharged) e o contrato extinto ${ }^{64}$. Para o efeito, a certeza da não verificação da condição equivale à sua não verificação (\$225 (2)). E qual é o momento relevante? A condição pode constar de uma cláusula onde se fixa uma data ou prazo limite para a sua ocorrência. Se essa estipulação não existir, o tribunal pode estabelecer um prazo razoável, como implied term ${ }^{65}$. Em Palmer v. Guillow $w^{66}$, o tribunal estabeleceu esse princípio, ainda que de forma muito generosa toda a vida do devedor, de quem dependia a verificação da condição (!).

Há ainda que estabelecer a fronteira material de verificação-não verificação. Se a condição é expressa ou implícita, ou seja, se resulta de estipulação das partes, ela só se considera verificada se ocorrer completamente (strict compliance) ${ }^{67}$; tratando-se de condição de fonte judicial (constructive condition), já é suficiente uma verificação em substância. Em Renovest Co.v. Hodges Development Corp., o tribunal considerou que as três condições das quais dependia a obrigação do comprador estavam sujeitas à regra da verificação completa e exata, na medida e que se tratava de express conditions precedent ${ }^{68}$.

Mas há que contar com princípios interpretativos que pretendem favorecer a verificação da condição: se for possível determinar se uma pessoa razoável, na posição do devedor, estaria satisfeita relativamente à verificação da condição, é preferida uma interpretação que considere verificada a condição se uma tal pessoa razoável, na posição do devedor, estivesse satisfeita (\$228).

Concluindo-se que a condição não se verificou, há que contar com o princípio da irrelevância do desconhecimento (ignorance immaterial): se a condição não se verificou o devedor tem o direito de suspender o cumprimento ou considerar o seu dever extinto, mesmo que não saiba que a condição não se verificou ${ }^{69}$.

64 Farnsworth on Contracts, II, 399-400.

65 Ibidem, 400.

66224 Mass. 1, 112 N.E. 493 (1916).

67 Farnsworth on Contracts, II, 401.

68135 N.H. 72, 600 A.2d 448 (1991), 79 e 453. E explicou a razão de ser da regra: "quando as partes expressamente condicionam o seu cumprimento à ocorrência ou não ocorrência de um evento, em vez de simplesmente incluir esse evento nas estipulações gerais do contrato, a expectativa de exata e completa verificação negociada pelas partes deve ser respeitada”.

69 Farnsworth on Contracts, II, 403. 
Os efeitos normais da não verificação da condição podem, no entanto, ser afastados se a condição for dispensada (excused). São causas de dispensa: waiver, breach ou decisão judicial para evitar forfeiture. Waiver significa dispensa por ato do devedor: depois da celebração do contrato original, o devedor promete realizar a prestação não obstante e não ocorrência da condição ou o atraso nessa ocorrência ${ }^{70}$. Breach corresponde ao incumprimento por parte do devedor que cause a não verificação da condição. Este é um ponto crítico, naturalmente. Esse incumprimento pode consubstanciar-se em não realização, por impedimento ou falta de cooperação, ou em recusa de cumprimento ${ }^{71}$. A boa fé e a lealdade impõem que, pelo menos, o devedor não impeça a ocorrência da condição. Mas pode ser mais do que isso. Pode ser exigido ao devedor que adote medidas positivas no sentido da realização da condição. Aqui não se trata de um dever de obter a condição - dever de resultado - , mas de um dever acessório de cooperação, de desenvolver todos os esforços no sentido de. Dever que nem sempre existe. Cabe ao tribunal apurar a existência ou não desse dever - a sua não existência é fundada na convicção de que o credor assumiu totalmente o risco da não ocorrência da condição ${ }^{72}$. Uma situação equiparada é a recusa (expressa) do devedor em cumprir mesmo que a condição se verifique. Ou seja, o devedor afirma que não cumprirá mesmo que a condição se verifique, quando a verificação da condição está de algum modo sob controlo do credor. Nesse caso, obviamente, a verificação da condição está dispensada se o credor não promoveu a sua ocorrência confiando na afirmação do devedor ${ }^{73}$.

Finalmente, os efeitos normais da não verificação da condição podem ser afastados caso a dispensa do dever resulte em disproportionate forfeiture, \$229:

"Na medida em que a não ocorrência de uma condição possa causar uma perda injustificada desproporcionada (disproportionate forfeiture), um tribunal poderá dispensar a ocorrência dessa condição, a não ser que a sua ocorrência seja uma parte substancial da transação acordada”.

70 Ibidem, 424.

71 Ibidem, 431.

72 Farnsworth on Contracts, II, 432-433. Cf. Lach v. Cabill et al., cit.; Renovest Co. v. Hodges Development Corp., cit., 81. E também já em Palmer v. Guillow, cit., 494.

73 Farnsworth on Contracts, II, 435. 


\section{LURDES VARGAS}

\section{E forfeiture significa:}

"recusa de compensação que surge quando o credor perde o seu direito à transação acordada, depois de ter confiado significativamente, por exemplo, preparando ou realizando a prestação na expectativa dessa transação" ${ }^{\text {"74 }}$.

De certo modo, trata-se da situação inversa de enriquecimento injustificado. O grau de forfeiture calcula-se comparando a extensão da forfeiture do credor contra a importância que tem para o devedor o risco que este pensava proteger (com a condição) e o grau da proteção (do devedor) que será perdida se a ocorrência da condição for dispensada na medida requerida para evitar forfeiture. Será esse o critério para apurar se a perda injustificada (forfeiture) é ou não desproporcionada ${ }^{75}$.

Mas ainda que haja essa perda injustificada desproporcionada, a condição só poderá ser dispensada se ela não for uma parte substancial da transação acordada (material). Nesse juízo é a importância da própria condição que é analisada. Ou seja, é crucial se aquela condição foi tomada pelas partes como fundamental para afastar um determinado risco ${ }^{76}$. Tratando-se de constructive condition ela é naturalmente material e não pode ser dispensada com base no $\$ 229$.

Em Acme Markets, Inc. v. Federal Armored Express, Inc. ${ }^{77}$ invocou-se expressamente o regime do $\$ 229$ e decidiu-se que a finalidade da condição, correspondente à emissão de um recibo, da qual estava dependente a responsabilidade da transportadora por perdas e desaparecimentos de sacos ou embalagens, deveria ser averiguada pelo tribunal recorrido, de forma a apurar-se se essa condição era ou não a material part of the agreement.

\footnotetext{
74 Restatement $2 n d, \$ 229$, comment b. Forfeiture é uma perda penalizante, efeito que é contrário ao direito dos contratos; se uma condição é imposta para fazer justiça, esse fim será defraudado se o resultado da imposição da condição for forfeiture. E se a não verificação de uma condição expressa deixar uma das partes com uma perda substancial — por não poder recuperar os projetados benefícios do contrato -, a condição deve ser dispensada: Claude D. Rohwer e Anthony M. Skrocki, Contracts..., 420. Também, Calamari and Perillo on Contracts, 466 ss.
}

75 Restatement 2 nd, $\$ 229$, comment b.

76 Um caso-exemplo de não verificação da condição muito elucidativo do que pode ser considerado material: Claude D. Rohwer e Anthony M. Skrocki, Contracts..., 418-419.

77437 Pa.Super. 41, 648 A.2d 1218 (1994). 
O tribunal de recurso considerou ser possível que o recibo fosse mais do que uma mera formalidade e funcionasse como uma proteção da transportadora contra reclamações injustificadas (aspeto que deveria ser apreciado pelo tribunal recorrido).

De notar que, em aplicação desta regra, o tribunal pode não dispensar totalmente a ocorrência da condição, mas dispensar a sua ocorrência no prazo devido.

\section{b) Impossibilidade superveniente (impracticability)}

Há impossibilidade superveniente da condição se esta for objetivamente inviável de se verificar ou pelo menos impraticável ${ }^{879}$.

A impossibilidade superveniente ou impracticability da condição é causa da sua dispensa, produzindo-se os efeitos normais do contrato, se (a) a condição não for uma parte substancial (material) da transação acordada; e (b) de outro modo resultar forfeiture ( $\$ 271)$.

O conceito de material é o mesmo visto a propósito da simples não verificaçã $0^{80}$. Condições acordadas meramente para fixar o tempo (relativamente às quais, aliás, se discute se são verdadeiras condições) ou o modo de realizar a prestação, bem como aquelas correspondentes a comunicações ou fornecimento de provas são, por regra, consideradas non-material ${ }^{81}$.

\section{Farnsworth on Contracts, II, 436-437.}

79 Restatement 2 nd, chapter 11 , introdutory note, 309 ss., contendo uma exposição geral do conceito de impracticability. Impracticability pode ultrapassar o que podemos considerar impossibilidade, inviabilidade ou impraticabilidade de verificação da condição e abranger o que se poderia designar de alteração das circunstâncias, situação que extravasa o âmbito da presente comparação e que não se abordará por si.

80 Para uma explicação bastante clara de substantial part of the agreed equivalent (ainda no âmbito do Restatement 1st), Arthur Corbin, "Supervening Impossibility of Performing Conditions Precedent", Columbia Law Review, 22 (1922): 527. Disponível in Faculty Scholarship Series, paper 2930, http:// digitalcommons.law.yale.edu/fss_papers/2930.

81 Calamari and Perillo on Contracts, 535. Estes casos também se podem resolver interpretando o evento de forma a afastá-lo do regime da condição. Recorde-se o já citado caso Ewell v. Landing: A obrigação de pagamento ficou sujeita à condição de o devedor vender a sua madeira. Com a morte do devedor essa condição tornou-se impossível. O evento foi considerado uma mera forma de marcar o momento do cumprimento. Tornando-se o evento impossível, deveria ser substituído por um prazo razoável. 


\section{LURDES VARGAS}

Em Harris v. Pacific Mut. Life Ins. Co. of California ${ }^{82}$ estava em causa a não verificação de uma condição da qual dependiam várias obrigações da seguradora. A seguradora alegou que não se verificou essa condição, correspondente ao fornecimento de prova da incapacidade do segurado pelo próprio. O tribunal decidiu que:

"O fornecimento da adequada prova da incapacidade era uma condition precedent da obrigação da seguradora de dispensar o futuro pagamento de prémios e pagar os benefícios de incapacidade, mas não era o próprio evento segurado. Era uma condição imposta para proteger a seguradora contra pedidos espúrios. O segurado incorreu em total e permanente incapacidade, o risco segurado; a incapacidade de fornecer a prova resultou dessa mesma incapacidade; e negar o pedido resultaria em forfeiture. A impossibilidade que dispensaria o dever de cumprir uma promessa dispensa a condition precedent, se a existência ou ocorrência da condição não é uma parte substancial da contrapartida (devida) pelo cumprimento do promitente e se a dispensa do cumprimento do promitente resultar em forfeiture."83

Em Grenier et al. v. Compratt Construction Company ${ }^{84}$ também se entendeu dispensar a condição com fundamento em impracticability. Tratava-se de um contrato de empreitada (construction), nos termos do qual a obrigação de pagamento da obra estava dependente da obtenção de um certificado escrito emitido pelo engenheiro dos serviços municipais, atestando que as estradas estavam concluídas. Os autores não conseguiram obter atempadamente o documento do engenheiro do município porque esse funcionário por princípio não emitia tais documentos.

O tribunal considerou que:

$82 \quad 137$ F.2d 272 (1943).

83 Página 273. No mesmo sentido, num caso paralelo, embora com uma fundamentação menos evidente: Mutual Life Ins. Co. of New York v. Johnson, 293 U.S. 335, 55 S.Ct. 154 (1934).

84189 Conn. 144, 454 A.2d 1289 (1983). No mesmo sentido, referindo-se ao regime do $\$ 303$ do anterior Restatement - que previa especialmente o caso de incapacidade do arquiteto, engenheiro ou inspetor, cujo certificado constituísse uma condition precedent —, regime agora absorvido no $\$ 271$ do atual Restatement, cf. U.S.A v. Klefstad Engeneering Co., 324 F.Supp. 972 (1971). 
"A normal imposição das condições está, no entanto, sujeita ao concorrente, mas igualmente bem estabelecido, princípio de que a ocorrência de uma condição pode ser dispensada em caso de impracticability, se a ocorrência da condição não é parte substancial de transação acordada e de outro modo resultar forfeiture. 2 Restatement (Second), Contracts $\$ 271 . " \$ 5$

O tribunal entendeu que a emissão do certificado camarário não era material part of the agreed exchange in the contract, porque o maior interesse do réu não era a carta em si, mas o que ela representava, ou seja, que a estrada estava aceitável de maneira a que a licença de ocupação pudesse ser emitida. Também se considerou que a imposição da condição resultaria em forfeiture para os autores (que já tinham executado a obra).

No que respeita à constructive condition, como já se disse, por natureza esta é sempre material. Logo, mesmo que se torne impossível por qualquer fator alheio às partes, nomeadamente ao credor, ela não é dispensada e o contrato não produz os seus efeitos, como se a condição simplesmente não tivesse ocorrido $^{86}$.

O regime do $\$ 271$ diverge significativamente do disposto no $\$ 229$, na medida em que aqui basta a existência de forfeiture, não sendo necessário que ela seja extrema ou desproporcionada.

\section{B) Da condition subsequent}

$O$ regime da impossibilidade superveniente da condition subsequent também é simples. Seja qual for o motivo pelo qual não se realize, é indiferente. Não se verifica, não produz os efeitos extintivos inerentes e o contrato mantém-se intocado ${ }^{87}$. As obrigações condicionadas não se extinguem.

Curiosa é a essência do regime do $\$ 230$. É dada relevância à impracticability, mas invertida: se a ocorrência do evento extintivo resultar de impracticability (que determinou não se conseguir evitar o evento), a obrigação condicionada pode não ser extinta ${ }^{88}$. Ou seja, trata-se como efeito esperado a não

85 p. 148.

86 Calamari and Perillo on Contracts, 535.

87 Arthur Corbin, "Conditions in the Law..., 756, nota 44.

88 Restatement 2nd $\$ 230$ (2) (b). 


\section{LURDES VARGAS}

verificação do evento; logo, se o evento suceder por facto fortuito que não tenha permitido impedir a sua ocorrência, então esse evento deve ser tratado como irrelevante ${ }^{89}$.

\section{Direito Português}

\section{Delimitação da figura}

\subsection{Aproximação ao Conceito}

A palavra condição é polissémica. Mesmo na linguagem jurídica ou dos juristas, condição pode ter um significado muito amplo, enquanto qualquer cláusula negocial ou, um pouco menos amplo, qualquer cláusula acessória dos negócios jurídicos ${ }^{90}$ - ex. "é celebrado o presente contrato com os seguintes termos e condições”. Mas também, num mesmo nível:

"O termo pode significar as circunstâncias que rodeiam certa situação ou evento, e que explicam a sua conformação ou conteúdo”; (...) a situação jurídica, social ou fáctica de determinada realidade, situação da qual em certa medida decorre o regime a que se encontra sujeita"; (...) conjunto de características de certa realidade ou elementos do seu regime ou conteúdo"; ou (...) os requisitos ou pressupostos, tomados globalmente, de certa realidade, ou da validade ou regularidade jurídica dela." ${ }^{\text {1 }}$

Num segundo patamar, mais estreito, condição pode ter dois significados: cláusula acessória típica que faz depender a produção, de todos ou de parte, dos efeitos de um negócio da ocorrência de um evento (positivo ou negativo) futuro e incerto ou então o próprio e respetivo evento futuro e incerto do qual depende a produção de efeitos do negócio jurídico. Quando nos referimos à cláusula

\section{Ibidem, comment a.}

90 Manuel Domingos de Andrade, Teoria Geral da Relação Jurídica, vol. II, 7.a reimpressão (1. edição e impressão 1953) (Coimbra: Almedina, 1992), 356.

91 João de Castro Mendes, “Da condição", BMJ, 263 (1977): 38-39. 
acessória tipica estamos naturalmente a afastar a fonte (origem) legal e a retirar toda a estipulação que se reporta ao tipo legal.

Tanto a cláusula acessória típica, como o respetivo evento condicional, podem designar-se de condição suspensiva, quando subordinam o início da produção dos efeitos do negócio; e condição resolutiva, quando subordinam a cessação dos efeitos do negócio. Independentemente da delimitação concreta da figura que se venha a fazer, condição no presente trabalho terá, por princípio e a não ser que se diga o contrário, os sentidos mais restritos - cláusula acessória típica e o respetivo evento condicional. É o respetivo regime que se pretende comparar (e é comparável). No art. ${ }^{\circ} 270 .^{\circ}$ condição tem ambos, ou qualquer um destes, dois sentidos, nas modalidades suspensiva e resolutiva. Pela maneira como está redigido, o preceito tanto pode referir-se à cláusula, como ao evento. Nos artigos seguintes, condição é utilizada ora no sentido de cláusula, ora no de evento condicional. Nos art. ${ }^{\circ}$ $22290^{\circ}$ ss. condição tem o sentido de cláusula acessória típica. Mas há que considerar que na lei, assim como na jurisprudência, nem sempre são estes os significados. E na redação dos contratos e negócios jurídicos ainda mais. E a polissemia pode ser fonte de equívocos ou pelo menos de dificuldades de interpretação.

\subsection{Origem}

O presente estudo comparativo tem por objeto o regime da cláusula acessória típica que tem a sua base nos art. ${ }^{\circ}$ s $2700^{\circ}$ ss. Trata-se, pois, das condições que correspondem a estipulações das partes. E de "estipulações das partes que nem constituem reprodução desnecessária de normas legais supletivas (...), nem são elemento fisionómico do tipo negocial em causa (...)." ${ }^{\prime 2}$ Nem também, obviamente, dos subtipos. Afastam-se, pois, todas condições, suspensivas ou resolutivas, constituídas por disposição legal, tais como as resultantes dos art. ${ }^{\circ} \mathrm{s} 469 .^{\circ}$ ss. do Código Comercial. Afasta-se também o elemento do contrato de seguro nos termos do qual a efetividade da obrigação do segurador (normalmente de natureza pecuniária, mas

92 Manuel Domingos de Andrade, Teoria..., II, 355. 
não necessariamente) fica dependente da ocorrência do risco (evento ou conjunto de eventos futuros e incertos $)^{93}$; o elemento do contrato de jogo nos termos do qual a definição das obrigações das partes fica dependente da ocorrência de um evento futuro e incerto; o elemento dos contratos de garantia nos termos do qual a exigibilidade da obrigação principal do garante fica dependente de um evento futuro e incerto ${ }^{94}$. Todos estes fazem parte integrante do tipo legal.

Ficam também fora do âmbito de condição aquelas que não correspondem a uma efetiva estipulação das partes, mas que se podem considerar motivações essenciais, bases da respectiva decisão de contratar. $\mathrm{O}$ que se pode entender por base do negócio em si não é uma condição, nem o será o que se possa entender por pressuposiçãa $0^{95}$. Diferente já será averiguar se determinadas circunstâncias associadas ao evento condicional podem integrar a base do negócio e se o regime do art. $^{\circ} 437 .^{\circ}$ pode ou não ser aplicável em caso da sua alteração.

Claro que a condição ser formulada pelas partes não significa, tal como quanto a qualquer outra estipulação negocial, que o respetivo apuramento não possa resultar de uma atividade interpretativa complexa. A interpretação em matéria de condição obedece às regras e princípios gerais da interpretação no negócio jurídico. Prevalece então, por princípio, o sentido que um declaratário normal, colocado no contexto objetivo e subjetivo do real declaratário, possa deduzir do comportamento do declarante, excepto se o declaratário conhecer a vontade real do declarante (art. ${ }^{\circ} 236 .^{\circ}$ ). Porém, nos negócios formais não pode a declaração valer com um sentido que não tenha um mínimo de correspondência no texto do respetivo documento ainda que imperfeitamente expresso (art. $\left.{ }^{\circ} 238 .^{\circ}, 1\right)$, a não ser que corresponda à vontade real das partes e as razões determinantes da forma do negócio se não oponham a essa validade (n. $\left.{ }^{\circ} 2\right)$. Isso quer dizer que as condições não expressas ou implícitas serão, por princípio, irrelevantes nos negócios formais, mas poderão ser identificadas pelo intérprete e produzir efeitos nos negócios consensuais. De

93 Carlos Ferreira de Almeida, Contratos, vol. III, 2. a edição (Coimbra: Almedina, 2013), 231 ss.

94 Carlos Ferreira de Almeida, Texto e Enunciado na Teoria do Negócio Jurídico, vol. I, Tese (Coimbra: Almedina, 1992), 354.

95 Manuel Domingos de Andrade, Teoria..., II, p. 355; Luís Carvalho Fernandes, Teoria Geral do Direito Civil, vol. II (Lisboa: Universidade Católica Portuguesa, 2010), 410 ss. 
qualquer modo, ainda que implícitas, devem corresponder a uma intenção de qualquer modo manifestada pelas partes e não a uma construção do tribunal exclusivamente fundada em razões de justiça. A fonte das condições objeto do presente estudo no direito português é, em exclusivo, o contrato celebrado pelas partes.

No Acórdão do Supremo Tribunal de Justiça, de 2-02-2006 ${ }^{96}$, entendeu-se que a cláusula inserida num contrato-promessa de um imóvel que fazia depender a celebração do contrato definitivo da cessação de um arrendamento sobre o prédio, a obter pela promitente-vendedora, tinha a natureza de um dever acessório da obrigação principal, com a natureza de uma verdadeira obrigação de resultado. $\mathrm{O}$ tribunal concluiu pela existência de uma espécie de presunção do caráter puro ou incondicionado das obrigações, que cabe ao réu-devedor ilidir ${ }^{97}$.

\subsection{O EVENTO}

Para existir uma condição e não um dever é preciso - embora não baste - que o evento do qual se faça depender a produção dos efeitos do negócio seja futuro e incerto. Os eventos passados, presentes, ou por outro motivo certos, não têm a natureza eventual que é essencial para a formulação hipotética (infra) e para se considerar que há pendência.

A primeira questão que se coloca, clássica, é se o evento tem que ser objetivamente futuro ou pode ser apenas subjetivamente futuro. Efetivamente, se um facto já ocorreu no passado ou no presente, mas não é conhecido pelas partes do contrato, mantém-se a incerteza do ponto de

\footnotetext{
96 Ac. STJ, de 2-02-2006, P.o 05B3578, in www.dgsi.pt.

97 O acórdão, com uma extensa e relevante fundamentação de direito, aborda a temática da interpretação:

"revestindo a condição carácter estipulatório, resultando da vontade e do comportamento declarativo dos contraentes, a qualificação da cláusula acessória adoptada em um dado contrato, como in casu, depende, em derradeira análise do respetivo conteúdo declarativo (...) O que não impede, atenta a natureza excepcional da condição (a regra é constituída pelos negócios puros) que «se houver dúvidas quanto à condicionalidade, é sobre o réu que deverá pesar o cargo da prova da condicionalidade do negócio e não sobre o autor a da sua incondicionalidade». (...) a ambiguidade objectiva, ou até a inexactidão, da expressão externa não impedem a relevância da vontade real, se o destinatário a conheceu. Houve coincidência de sentidos (o querido e o compreendido), logo, este é o sentido decisivo" - p. 22.
} 
vista das mesmas partes. Este é um ponto de vista possível, mas minoritário na nossa doutrina ${ }^{98}$. Contra, considerando que não se trata de uma condição em sentido próprio, mas apenas de uma condição imprópria, a esmagadora maioria99.

Não é uma questão fácil. Se há pendência enquanto há incerteza, relativamente aos eventos passados ou futuros mas desconhecidos, essa incerteza existe. Em todo o caso, mesmo considerando-se que esta não é uma condição em sentido próprio, entende-se que muitas regras do regime da condição são aplicáveis por analogia ${ }^{100}$.

O requisito de incerteza afasta os eventos cuja ocorrência é necessária - ex. morte - que terão a natureza de termo incerto e não de condição, aplicando-se-lhes o regime daquele (que será o da própria condição, com as necessárias adaptações, art. $\left.^{\circ} 278 .^{\circ}\right)$. E afasta o caso oposto, ou seja, dos eventos impossíveis (originariamente). O problema da possibilidade e impossibilidade, núcleo deste trabalho, será tratado infra.

\subsection{Abrangência}

Um outro aspeto polémico. Será que os efeitos da condição, enquanto cláusula acessória típica, são necessariamente totais ou podem ser parciais?

98 Tanto quanto se conseguiu apurar, da doutrina clássica, apenas Menezes Cordeiro é de opinião que um evento passado ou presente, mas não conhecido pelos sujeitos negociais pode ser a condição - António Menezes Cordeiro, Tratado de Direito Civil, I Parte Geral, tomo I, 3. ${ }^{a}$ ed. (Coimbra: Almedina, 2011), 716 .

99 Manuel Domingos de Andrade, Teoria..., II, 358; João de Castro Mendes, Teoria Geral do Direito Civil, vol. II, (edição revista em 1985) (Lisboa: AAFDL, 1995), 320; Luís Carvalho Fernandes, Teoria..., 414; Inocêncio Galvão Teles, Manual dos Contratos em Geral, 4. ${ }^{a}$ edição, reimpressão (Coimbra: Wolters Kluwer/ Coimbra Ed., 2002), 261; Heinrich Ewald Hörster e Eva Sónia Moreira da Silva, A Parte Geral do Código Civil Português: Teoria Geral do Direito Civil, 2. a ed. (Coimbra: Almedina, 2019), 547; Carlos Alberto da Mota Pinto, Teoria Geral do Direito Civil, Editado por António Pinto Monteiro e Paulo Mota Pinto, 4. ${ }^{a}$ edição (Coimbra: Coimbra Ed., 2005), 562; José de Oliveira Ascenção, Direito Civil, Teoria Geral, vol. II, 2. a edição (Coimbra: Coimbra Ed., 2003), 345; Pedro Pais de Vasconcelos, Teoria Geral do Direito Civil, 9. ${ }^{a}$ edição (Coimbra: Almedina, 2019), 606. "Se o acontecimento já se verificou e as partes desconhecem a sua produção, há erro ou ignorância; e da mesma forma, se ele definitivamente não se pode verificar. Ainda que as partes saibam que ele já se verificou (que o jogo já terminou, embora não saibam qual o resultado), continua a não ser possível a condição «se ganhar», pois não se verifica a situação de pendência que é essencial na condição." José de Oliveira Ascenção, Direito Civil, II, 345.

100 Ibidem, 345, nota 525. 
De outro modo, questiona-se se só há condição quando todos os efeitos do negócio ficam na dependência do evento condicional ou se também há condição em sentido próprio quando apenas parte dos efeitos negócio são condicionados. A questão é omitida por boa parte da doutrina nacional. Tendo presente o regime do art. ${ }^{\circ} 270 .^{\circ}$ ss, é possível sustentar-se que apenas há condição em sentido próprio quando todos os efeitos do contrato são afetados ${ }^{101}$. Tem que se reconhecer que pelo menos o regime do art. ${ }^{\circ} 271 .^{\circ}$ está construído para a condição de efeitos totais. No caso de uma condição contrária à lei ou originariamente impossível que tenha por objeto apenas parte dos efeitos de um contrato, não faz sentido que a consequência seja a nulidade de todo o contrato ( rrt. $\left.^{\circ} 271 .^{\circ}\right)$. Mas, ainda assim, é defensável que há condição em sentido próprio, enquanto cláusula acessória típica, sempre que a condição contém os elementos ou requisitos enunciados no art. ${ }^{\circ} 270 .^{\circ}$ e a mesma função. Neste ponto de vista, que me parece correto, a condição pode ter por objeto apenas parte dos efeitos de um negócio jurídico ${ }^{102}$. $\mathrm{O}$ art. ${ }^{\circ} 270 .^{\circ}$ fala "dos efeitos" e não indica que são todos. Funcionalmente não há diferenças. E o regime dos art. ${ }^{\circ}$ s $272 .^{\circ}$ ss. é tão adequado para as condições totais, como para as parciais. Por outro lado, no que respeita aos negócios gratuitos, o regime dos art. ${ }^{\circ}$ s $22300^{\circ}$, aplicável diretamente ao testamento e ex vi art. ${ }^{\circ} 967 .^{\circ}$ à doação, foi previsto expressamente para a condição de efeitos parciais: nos termos do art. $^{\circ} 2229 .^{\circ}$, o "testador pode sujeitar a instituição de herdeiro ou a nomeação de legatário a condição suspensiva ou resolutiva”.

De qualquer modo, defina-se a condição parcial como própria ou como imprópria, as consequências não devem ser muito diferentes. $\mathrm{O}$ regime do art. $^{\circ} 271 .^{\circ}$ nunca poderia ser aplicado diretamente sem adaptações. Será aplicável à condição parcial por analogia e com adaptações (de que se falará infra, quanto à condição originariamente impossível). Quanto às demais

101 Carlos Ferreira de Almeida, Texto e Enunciado..., 353-354; Manuel Domingos de Andrade, Teoria..., II, 356. Não expressamente, mas definindo condição de maneira a que só a condição de efeitos totais é compreendida, Inocêncio Galvão Teles, Manual dos Contratos..., 258.

102 Claramente a favor da condição com efeitos parciais, João de Castro Mendes, Teoria Geral..., 318; João de Castro Mendes, "Da condição", 43 e 60; Heinrich Ewald Hörster e Eva Sónia Moreira da Silva, $A$ Parte Geral..., 548 (os autores não abordam expressamente a questão, mas dão como exemplo de condição a cláusula de reserva de propriedade); Pedro Pais de Vasconcelos, Teoria Geral..., 603; Nuno Baptista Gonçalves, Do Negócio sob Condição (Estudo de Direito Civil), Tese (Lisboa: [s.n.], 1993), 10. 


\section{LURDES VARGAS}

disposições, $\operatorname{art}^{\circ}{ }^{\circ}$ S $272 .^{\circ}$ ss., ou se entende que são aplicáveis diretamente à condição parcial, ou serão aplicáveis por analogia.

\subsection{Formulaçã̃o}

No direito português só há condição quando o evento e os efeitos que se pretendem associar ao mesmo são considerados em termos hipotéticos. "Se". "X promete vender o prédio y e $\mathrm{Z}$ promete comprar se o projeto de construção for aprovado pelos serviços competentes"; "a doação do meu quadro a W é feita na condição de (se) eu me mudar para Sidney em Setembro"; "a doação do meu terreno x a P, em .../.../...., é feita na condição de P tratar e cultivar esse meu terreno até essa data”. Ou então: "caso seja indeferida a alteração do alvará, o presente contrato de trespasse resolve-se automaticamente”; "em caso de recusa da certificação oficial dos produtos u junto do Instituto $\mathrm{V}$, o presente contrato de manutenção resolve-se automaticamente". Em todos os casos há uma clara construção hipotética e não perentória ${ }^{103}$. Acontece $\mathrm{x}$ apenas se suceder z. É esta formulação que permite distinguir condição de outras figuras, tais como o dever ou o modo. Assim,

"a condição suspende mas não obriga, o modo obriga mas não suspende. Semelhante distinção só vale em relação à condição suspensiva. (...) Pode dizer-se que, na condição suspensiva potestativa, a actividade prevista é um ónus do beneficiário; no modo, é uma obrigação."104

Mas o confronto da condição resolutiva com o modo já é mais complicado. Em ambos os casos o negócio produz efeitos imediatos e o não cumprimento determina a resolução da liberalidade. E na análise ou interpretação de casos concretos a dificuldade pode aumentar: "A linguagem usada pelas partes fornece escasso apoio, pois frequentemente se fala em condição para significar modo, e em encargo para significar

103 Manuel Domingos de Andrade, Teoria..., II, 356.

104 José de Oliveira Ascenção, Direito Civil, II, 361. 
condição." ${ }^{105}$ Ora, a distinção é fundamental. Na condição, a resolução opera automaticamente; enquanto no modo, ocorrendo incumprimento, tem que ser pedida ( art. $^{\circ}$ s $966 .^{\circ}$ e $2248 .^{\circ}$ ). E, sobretudo, os efeitos resolutivos da condição afetam terceiros, enquanto os do modo em princípio não ${ }^{106}$.

Vasta jurisprudência aborda o problema da distinção entre condição e dever. Se, por um lado, daí podem resultar critérios de distinção, por outro lado, há decisões no mínimo polémicas que realçam ainda mais as dificuldades da distinção.

O Acórdão do Supremo Tribunal de Justiça, de 10-12-2009 ${ }^{107}$, pode ser considerado modelar. A fundamentação do acórdão começa por definir a figura jurídica condição, delimita-a, analisa os seus efeitos, e distingue condição suspensiva e resolutiva, condição própria e condição legal, com abundantes referências doutrinárias. A subsequente análise e enquadramento dos factos acaba por surpreender. Tratava-se de um contrato de compra e venda de imóvel, nos termos do qual a autora vendeu à ré uns lotes de terreno. Do contrato constava o seguinte: "No prazo máximo de cento e oitenta dias a contar da data da assinatura da presente escritura, deverá o segundo outorgante (ré) dar início à implantação dos projectos no terreno"; "Doze meses após a data do alvará-licença de construção, deverão as unidades estar em completa laboração dentro dos moldes apresentados pelos projectos aprovados e licenciados"; e "O não cumprimento de qualquer destes prazos implica que a Câmara Municipal de Pombal tome posse dos lotes no estado em que os mesmos se encontrarem, sem qualquer direito à importância já entregue ou a qualquer indemnização por parte do adquirente, bem como das benfeitorias existentes". A Relação, divergindo da primeira instância, considerou que as duas primeiras disposições contratuais (transcritas) consubstanciavam verdadeiros deveres para a compradora e que a última era uma cláusula resolutiva expressa, sujeita ao regime dos art..$^{\circ}$ s $432 .^{\circ}$ ss. . Em consequência, revogou parcialmente a decisão da primeira instância, declarando a ineficácia da resolução decretada relativamente a uma hipoteca constituída a favor do credor

105 Ibidem, 362.

106 Ibidem, 362.

107 Ac. STJ, de 10-12-2009, P.o 312-C/2000.C1-A.S1, in www.dgsi.pt. 


\section{LURDES VARGAS}

BB. O Supremo considerou tratar-se antes de um contrato de compra e venda sujeito a uma condição resolutiva, a qual se verificou, o que deu origem à automática resolução do contrato e consequente reversão da propriedade para a vendedora condicional, extinguindo-se os efeitos da hipoteca que o credor condicional (comprador) celebrara com o banco BB durante a pendência da condição. Face à redação das citadas cláusulas, dúvidas se levantam relativamente à interpretação e enquadramento dos factos feitos pelo Supremo. Condição ou conjunto de deveres associados a uma cláusula resolutiva?

Outros casos poderão igualmente ilustrar a dificuldade em distinguir condição e dever ${ }^{108}$.

\section{Modalidades RELEVANTES}

\subsection{QUANTO AO MOMENTO DE AFETAÇÃo}

A modalidade que determina o início da produção dos efeitos do contrato é a condição suspensiva (ou inicial); enquanto que a condição resolutiva (ou final) determina a cessação dos efeitos do contrato (art. ${ }^{\circ} 2700^{\circ}$ ). Ambas produzem os seus efeitos retroativamente ${ }^{109}$. Tanto na condição suspensiva, como na resolutiva, o evento condicional pode ser um facto positivo ou um facto negativo. Uma condição resolutiva que seja facto negativo pode ser confundida com uma condição suspensiva e vice versa: "os efeitos do presente contrato ficam dependentes da obtenção da aprovação do loteamento”. Condição suspensiva positiva ou resolutiva negativa? "A questão de saber se uma condição é suspensiva ou resolutiva é uma questão de interpretação do negócio jurídico, de averiguar a vontade real das partes", afirmou o Supremo num determinado processo. ${ }^{110}$ É efetivamente uma questão de interpretação. Embora o

108 Ac. STJ, de 2-02-2006, cit.; Ac. STJ, de 16-12-2010, P.o 2904/05.TBCBR.C1.S1, in www.dgsi.pt. 109 Ac. STJ, de 19-10-2004, P.o 04B2740, in www.dgsi.pt: "No contrato de compra e venda condicionada, se a condição é suspensiva, sobrevinda esta, a venda pode produzir os seus efeitos e estes são considerados como tendo sido produzidos a partir da conclusão do contrato; pelo contrário, se a condição é resolutiva, os efeitos do contrato são retroactivamente anulados e o vendedor, voltando outra vez a ser proprietário, é considerado como nunca tendo perdido essa qualidade."

110 Ac. STJ, de 23-10-2003, Recurso n. ${ }^{\circ}$ 2509/03, CJ Supremo, XI (2003), n. ${ }^{\circ} 3:$ 108-111. 
critério da vontade real das partes não seja exatamente o prevalecente, mas sim o da impressão do destinatário (art. $\left.{ }^{\circ} 236 .^{\circ}, 1\right)$, temperado com a exigência de uma mínima correspondência textual $\left(\text { art. }^{\circ} 238 .^{\circ}, 1\right)^{111}$. E, perante a elevada dificuldade de apurar o sentido da declaração, há que encontrar critérios auxiliares. Em Acórdão de 3-04-2003 ${ }^{112}$, o Supremo estabeleceu determinados princípios na interpretação dos negócios condicionais. Relativamente à questão concreta de optar por condição resolutiva ou suspensiva, o Supremo construiu uma presunção judicial: "Se o negócio está cumprido, ou se as partes se obrigaram a realizar imediatamente determinadas prestações do contrato, presume-se que estas optaram pela condição resolutiva." 113

A diferença de efeitos entre uma e outra modalidade da condição determina o regime de ónus da prova, expresso no $\operatorname{art}^{\circ}{ }^{\circ} 343 .^{\circ}, 3$, mas que se pode considerar decorrente da regra geral:

"A condição suspensiva só produz inicialmente efeitos potenciais, prodrómicos ou preliminares, pelo que a parte que pretende valer os efeitos consolidados do negócio deve provar que se verificou o evento condicionante. A condição resolutiva produz inicialmente os efeitos normais do negócio, pelo que cabe à outra parte provar que se verificou o evento condicionante que os extinguiu. Isto corresponde às regras da distribuição do ónus da prova anteriormente estabelecidas no $\operatorname{art}^{\circ} 342 .^{\circ}, n^{\circ}$ s 1 e 2, do mesmo Código, sendo assim uma norma inútil." ${ }^{114}$

\subsection{QuANTO AO ÂMBITO}

Face ao regime dos $\operatorname{art}^{\circ}{ }^{\circ}$ s $271 .^{\circ}$ ss., uma distinção entre condição (suspensiva ou resolutiva) de todos os efeitos do contrato e condição de parte dos efeitos é essencial. Como já se viu, esse regime, tal qual, está preparado para a condição total e não para a parcial.

111 Ac. STJ, de 19-10-2004, cit. .

112 Ac. STJ, de 3-04-2003, P. 03A881, in www.dgsi.pt.

113 Entendendo que este é o critério preferível, Manuel Domingos de Andrade, Teoria..., II, 367.

114 Ibidem. Sobre ónus da prova da condição suspensiva, também: Ac. STJ, de 23-10-2003, cit., e Ac. Rel. Coimbra, de 26-11-2002, Recurso n. ${ }^{\circ}$ 2575/02, CJ, XXVII (2002), n. ${ }^{\circ}$ 5: 21-22. 


\section{LURDES VARGAS}

Mesmo na doutrina que define condição como cláusula acessória que pode incidir sobre a vigência de todos ou parte dos efeitos do contrato falta uma análise das respetivas consequências. Falta determinar qual o regime aplicável à condição parcial.

Sendo o núcleo deste trabalho a possibilidade e a impossibilidade da condição, reenvia-se a análise das diferenças de regime entre uma e a outra modalidade para essa parte do trabalho - infra.

\subsection{QUANTO À ORIGEM DO EVENTO}

A ténue fronteira entre condição e outras figuras jurídicas volta a estar presente nesta classificação. Uma condição pode referir-se a um acontecimento da natureza ou a um acontecimento humano de um terceiro - ex. autorização administrativa ou de entidade privada (condição casual); ou a um ato de uma das partes - tratando-se de negócio obrigacional, do credor ou do próprio devedor (condição potestativa). As condições que conjugarem os dois tipos de acontecimentos, ou seja, um acontecimento natural ou ato de terceiro e um ato de uma das partes serão mistas (exemplo de escola, "condição de casar" - envolve um ato de uma parte contratual e um ato de um terceiro).

A condição designada de potestativa suscita novas dificuldades de delimitação face a outras figuras jurídicas e dúvidas sobre a sua admissibilidade. As condições potestativas podem ser objeto de duas classificações: condições a parte debitoris versus condições a parte creditoris; condição potestativa não arbitrária versus condição potestativa arbitrária (ou condição meramente potestativa).

Numa leitura possível, a condição potestativa - respeite ela a um ato do credor ou a um ato do devedor - corresponde ao "direito potestativo de deter ou desencadear a eficácia do negócio, consoante seja resolutiva ou suspensiva"115.

Noutro ponto de vista, quando se pretende estimular o comportamento da contraparte negocial, pode alcançar-se esse objetivo pela criação de uma prestação ou então fazendo esse comportamento o conteúdo de uma condição.

115 António Menezes Cordeiro, Tratado..., I, I, 715. 
No primeiro caso, surge uma obrigação ("dou-te x e tu escreves um livro"); no segundo caso, surge um ónus sobre o credor da obrigação condicional ("dou-te $\mathrm{x}$ se tu escreveres um livro") ${ }^{116}$. "Se aceitar o primeiro negócio, o declaratário vincula-se a escrever um livro com a contrapartida de $\mathrm{x}$; se aceitar o segundo, o declaratário não se vincula a coisa alguma, embora aceite uma situação jurídica em que duma sua conduta lhe advém (automaticamente) um benefício." 117

Considera-se correto o último ponto de vista. Não há nenhuma incompatibilidade entre a qualificação como ónus e como condição. Este ónus é uma condição porque o benefício que advém da conduta é a produção dos efeitos (todos ou parte) de um negócio, nomeadamente dos seus direitos de crédito.

Em todo o caso, as condições ditas potestativas aumentam o grau de dificuldade de identificação e interpretação.

A outra distinção, entre condições potestativas arbitrárias e não arbitrárias, coloca outra ordem de problemas. A condição arbitrária ou meramente potestativa é aquela que não manifesta qualquer interesse sério. Ou consiste num puro querer ("dou-te cem euros se tu quiseres" ou "dou-te cem euros se eu quiser”) ou então numa exigência sem qualquer justificação atendível para os interesses em jogo no negócio (“dou-te cem euros se pulares cem vezes”). Por contraposição, a condição potestativa não arbitrária toma por evento condicional um ato relevante para os interesses em jogo: "dou-te o meu quadro $x$ se eu viajar para Sydney" ou "dou-te o meu quadro x se tu te mudares para Lisboa"; ou então, "o pagamento do prémio de x euros fica dependente da subida para a primeira liga na época z" ou "as despesas z serão reembolsadas na condição de serem apresentadas as respetivas faturas detalhadas no prazo de 15 dias após a data das mesmas despesas”.

Coloca-se a questão de saber se as da primeira modalidade, as condições arbitrárias, são admissíveis ou não. A posição clássica sobre esta matéria é (ou já foi): a condição potestativa arbitrária a parte debitoris é inadmissível; a condição potestativa arbitrária a parte creditoris é inútil. $\mathrm{O}$ primeiro caso porque se trataria de uma promessa não vinculante; o segundo caso porque é próprio da obrigação que o credor a possa exigir

116 João de Castro Mendes, “Da condição", 51.

117 Ibidem, 51. 


\section{LURDES VARGAS}

se quiser ${ }^{118}$. Mas há quem entenda que não é bem assim. Tratando-se de um contrato bilateral, nunca seria inútil, nem inadmissível, porque pelo menos sempre se vincula o outro contratante ${ }^{119}$. Num outro sentido, tratando-se de condição arbitrária a parte creditoris, entende-se admissível que fique ao arbítrio do credor, que pode resolver o contrato também se quiser; e a parte debitoris, se remetesse para o regime do $\operatorname{art}^{\circ}{ }^{\circ} 778 .^{\circ}, 2$ seria uma cláusula válida, e, caso contrário, seria nula porque criaria uma obrigação natural exclusivamente fundada na vontade, inadmissível (art. ${ }^{\circ}$ 402. $\left.{ }^{\circ}\right)^{120}$. Nos contratos translativos de direitos reais também seriam válidas tais cláusulas: a cláusula resolutiva-potestativa da parte do vendedor é válida (venda a retro, art. ${ }^{\circ}$ s $932 .^{\circ}$ e $933 .^{\circ}$ ); e a condição resolutiva da parte do comprador, assim como a condição suspensiva da parte de qualquer um deles também seria válida ao abrigo da autonomia da vontade ${ }^{121}$. Num outro modo de ver, que me parece correto, as condições potestativas arbitrárias não são verdadeiras condições: as "condições potestativas arbitrárias suspensivas são melhor qualificáveis como pactos de opção ou como propostas contratuais; as condições potestativas arbitrárias resolutivas como cláusulas de resolução ou denúncia." ${ }^{122}$

\section{FunÇão e natureza}

A condição é normalmente apresentada como uma cláusula acessória típica do negócio jurídico - o que preliminarmente se aceitou, por comodidade, apenas para delimitar a figura perante as condições de origem legal. Mas esta simples definição pode também envolver uma opção sobre a natureza da figura. A questão pode colocar-se na seguinte forma: a condição é um elemento do negócio ou é um atributo do negócio.

\footnotetext{
118 Carlos Alberto da Mota Pinto, Teoria Geral..., 566.

119 Ibidem.

120 João de Castro Mendes, Teoria Geral..., 331.

121 Ibidem, 332.

122 Pedro Pais de Vasconcelos, Teoria Geral..., 610.
} 
Na primeira perspetiva, a condição seria algo que acresce ao negócio, uma parte autónoma do seu conteúdo dispositivo.

"O eventual acontecimento futuro previsto na condição não se incorpora no contrato, não se integra ou deixa absorver nele, nem mesmo na condição suspensiva, em que simplesmente acresce ao negócio, fechando o ciclo de um facto complexo de produção sucessiva, de que são peças ou elementos o contrato condicionado e o facto condicionante."123

Então faria sentido qualificar-se como cláusula acessória.

Noutro modo de ver, a condição é um mero atributo ou modo de ser do negócio, não algo que acresce ao negócio. Será então uma modalidade de negócio e não uma cláusula acessória, no sentido material do termo. ${ }^{124}$ Considerando-se a condição como algo que integra o próprio negócio justificar-se-ia o regime-regra: a invalidade da condição determina a invalidade de todo o negócio. Mas é claro que, face ao atual direito positivo, esta decorrência relativizou-se. O regime-regra dos negócios gratuitos é o inverso (como se verá infra) ${ }^{125}$.

Há uma terceira via. É possível considerar tratar-se de uma cláusula acessória, mas que faz corpo com o negócio. "O negócio condicionado constitui um todo único, um monólito." 126 Pois, "a estipulação condicional não se desdobra em duas declarações de vontade, sendo a segunda limitativa da primeira. Constitui uma declaração de vontade única e incindivel, como a própria volição que exprime." 127 E não é incompatível com a qualificação de acessória. A natureza acessória resultará simplesmente de se tratar de "um elemento acidental do negócio jurídico (não é pois, seguramente, um elemento típico do tipo negocial ${ }^{128}$ )." ${ }^{129}$ Esta perspetiva é a que me parece correta.

123 Inocêncio Galvão Teles, Manual dos Contratos..., 260.

124 João de Castro Mendes, “Da condição”, 53-60.

125 Ibidem.

126 Manuel Domingos de Andrade, Teoria..., II, 357.

127 Ibidem. E também no sentido da natureza unitária do negócio condicionado, António Menezes Cordeiro, Tratado..., I, I, 718.

128 Ver nota 107.

129 Na expressão do Ac. STJ, de 10-12-2009, P. 312-C/2000.C1-A.S1, 8, in www.dgsi.pt. Porém, 


\section{LURDES VARGAS}

Quanto à função, é pacífico reconhecer duas finalidades: a) Previsão de eventualidades futuras (distribuição do risco); e b) Influência no comportamento do próprio credor ou do próprio devedor ${ }^{130}$. A primeira significa que a "condição permite moldar antecipadamente os efeitos do negócio jurídico às eventualidades que se podem vir a verificar (mas que igualmente se podem não verificar) na evolução da trama de interesses que o negócio é chamado a regular." ${ }^{131}$ A segunda que a condição pode estimular, incentivar, o comportamento do credor ou do próprio devedor — é o que sucede nas condições ditas potestativas.

E ainda pode ser reconhecida uma terceira finalidade: como prémio ou contrapartida. Premiar um esforço adicional daquele a quem se destina (o credor). ${ }^{132}$ Mas na verdade esta finalidade confunde-se de certa maneira, ou sobrepõe-se, com a segunda.

\section{PoSSIBILIDAde E IMPOSSIBILIDADE}

\subsection{Possibilidade E IMPOSSIBILIDAde ORIGINÁRIA: CONCEITO}

O que é uma condição possível e uma condição impossível?

Possibilidade e impossibilidade são conceitos conhecidos a propósito do objeto do negócio jurídico. O conceito-base de possibilidade v. impossibilidade e alguns critérios de distinção podem ser transpostos para a análise da possibilidade e impossibilidade do evento condicional.

Comece-se pelo lado positivo. O evento condicional é possível quando se pode materializar, suceder. Seja esse evento positivo - um acontecimento —, seja ele negativo — não acontecer algo. Isso quer dizer que ele tem que ser viável num ponto de vista prático material e jurídico se envolver um ato jurídico. Tem que haver possibilidade física e legal (art. $\left.{ }^{\circ} 271 .^{\circ}, 2\right)$.

note-se, neste Acórdão o Supremo termina afirmando que a condição não constitui um todo com o negócio, a condição simplesmente acresce ao negócio.

130 João de Castro Mendes, "Da condição”, 45-47.

131 Ibidem, 45.

132 bidem, 47. 
Tradicionalmente, a doutrina trata a possibilidade e impossibilidade da condição sob a epígrafe condições impróprias. A ideia de base é: não há verdadeiramente condição porque já se sabe que não pode suceder ${ }^{133}$. Não parece assim tão simples.

Fora os casos limite, casos de escola nesta matéria - "se tocares o céu com um dedo", "se beberes toda a água do mar", "se viajares para França e não saíres de Portugal", "se validamente casares com a tua filha" muitas condições podem numa primeira leitura parecer possíveis, viáveis, e depois de reflexão, bem analisadas, revelarem-se impossíveis - neste caso impossíveis desde o início e não apenas supervenientemente. "Se construíres uma escultura usando o metal z" pode parecer viável. Mas é impossível se constatarmos que o metal não existe para comercialização. Claro que isto já nos leva a um outro problema: a fronteira entre condição impossivel e condição difícil e a improvável. ${ }^{134}$ Por outro lado, se estivermos a falar de condições consubstanciadas num ato jurídico ou que incluam um ato jurídico, a fronteira possibilidade-impossibilidade ainda pode ser mais difícil de descortinar. "O presente trespasse é celebrado na condição de o estabelecimento obter alvará para a atividade y”. Sucede que a atividade y não pode ser desenvolvida em zonas urbanas, como é o caso. Nestes casos a impossibilidade não é óbvia. Do mesmo modo que não é sustentável dizer que não há verdadeiramente contrato quando o seu objeto é impossível, também não fará sentido sustentar que não há verdadeira condição se ela é impossível. Até porque a impossibilidade pode não ser total, mas apenas parcial.

Seja qual for a natureza da condição impossível, cabe analisar os limites entre condição possível e condição impossível.

Um aspeto que parece por natureza complicado e polémico é a delimitação entre condição legalmente impossível e condição possível, mas contrária à lei. A diferença é muito relevante se estivermos a falar de uma condição

133 Manuel Domingos de Andrade, Teoria..., II, 359; João de Castro Mendes, "Condição necessária, impossível e indeterminável”, Direito e Justiça, vol. I (1980), n. ${ }^{\circ}$ 1: 59; Luis Carvalho Fernandes, Teoria..., 414; Heinrich Ewald Hörster e Eva Sónia Moreira da Silva, A Parte Geral..., 547; José de Oliveira Ascenção, Direito Civil..., II, 347; Carlos Alberto da Mota Pinto, Teoria Geral..., 562; Pedro Pais de Vasconcelos, Teoria Geral..., 606.

134 Segundo João de Castro Mendes, a condição improvável é uma realidade diferente da condição impossível — "Condição necessária...., 65 


\section{LURDES VARGAS}

resolutiva em contrato oneroso: se contrária à lei, o negócio é nulo; se legalmente impossível, só a condição é nula ( $\operatorname{art.}^{\circ} 2710^{\circ}$ ).

Num modo de ver e definir, a condição legalmente impossível é mesmo irrealizável (“dou-te x se casares (validamente) com tua filha”), enquanto que a contrária à lei, a condição em si é realizável embora contra a lei ("dou-te $\mathrm{x}$ se matares") ${ }^{135}$.

Uma outra perspetiva bem diferente é considerar que a condição é legalmente impossível "todas as vezes que se reporte a um acto contrário à lei". Em consequência, restringe-se os casos de condição imprópria dentro da condição impossível. A condição legalmente impossível só deixa de ser uma verdadeira condição, e será uma condição imprópria, "sempre que a eficácia do negócio jurídico fica dependente da válida celebração de outro acto jurídico que a lei não admite"136. O que faz sentido. Porém, fica por explicar o que será a condição simplesmente contrária à lei, que em parte tem um regime diverso da legalmente impossível.

A primeira leitura parece a mais lógica. Pois só ela explica uma diferente previsão e diferente regime para as duas situações de desvalor. E também está consagrada em jurisprudência. No Acórdão do Supremo Tribunal de Justiça, de 19-10-2004 ${ }^{137}$, aceitou-se esse critério de delimitação da condição legalmente impossível:

"A verdadeira condição impossível é a que de todo não pode realizar-se, por impossibilidade física ou legal. A impossibilidade legal propriamente dita consistirá em ter-se posto como condição de eficácia de um negócio a realização válida de outro que por lei não pode realizar-se validamente." ${ }^{138}$

135 oão de Castro Mendes, “Condição necessária...”, 66.

136 Inocêncio Galvão Teles, Manual dos Contratos..., 268. A nota 254 da mesma página também não é esclarecedora: referindo-se ao art. ${ }^{\circ} 2800^{\circ}$, diz que fala em objeto ou negócio física ou legalmente impossivel e depois contrário à lei, contrário à ordem pública, ofensivo dos bons costumes. O que seriam todas fórmulas abrangidas no conceito de impossibilidade legal. Será que pretende estender esta coincidência de desvalores do ato à condição? Mas como, face ao diferente regime dos $n .^{\circ} \mathrm{s} 1$ e 2 do art. $271 .^{\circ}$ ? Num sentido aparentemente próximo, considerando condições impossíveis aquelas que se referem a um ato por si contrário à lei, Pires de Lima e Antunes Varela, Código Civil Anotado, vol. I, 4. ${ }^{a}$ edição (Coimbra: Coimbra Ed., 1987), anotação ao art. $^{\circ} 271 .^{\circ}$.

137 Já citado.

138 Citando Manuel Domingos de Andrade, Teoria..., II, 370. 
Aceita-se este sentido de impossibilidade legal. Assim, não serão consideradas legalmente impossíveis as condições simplesmente contrárias à lei ${ }^{139}$.

Uma outra questão, comum à condição física ou legalmente impossível, respeita a saber qual a relevância do conhecimento e convicção das partes.

"O conceito de condição impossível é objectivo, e nada tem que ver com a ideia da parte sobre a possibilidade ou impossibilidade da condição que apôs. (...) Se a interpretação normal da declaração a não destruir, a convicção secreta ou oculta de impossibilidade da condição em nada revela. Se ela é objectivamente impossível, o acto é ineficaz por isso; se é objectivamente possível, o acto é válido, não obstando a isso a reserva mental do declarante (e salva a restrição da parte final do n. ${ }^{\circ} 2$ do art. $244 .^{\circ}$ do Código Civil português)." ${ }^{140}$

O juízo de impossibilidade é objetivo. O que não quer dizer que as convicções ou intenções das partes não sejam relevantes, sobretudo no que respeita aos efeitos da impossibilidade.

A impossibilidade pode ser total ou parcial, no sentido de a condição ser absolutamente irrealizável ou ser irrealizável apenas em parte ou com determinado âmbito: "se viajares até Júpiter" é totalmente impossível; "se construíres uma escultura com o metal z (jazidas esgotadas, impossível de adquirir)", é impossível com aquele metal, mas pode ser com outro, pelo que será parcialmente impossível; "se viajares até Sydney nas próximas 12 horas" é impossível nesse espaço de tempo, mas se substituirmos por “nas próximas 24 horas” já é viável. Esta distinção é relevante para os efeitos do regime da impossibilidade.

Outra distinção relevante é entre condição absolutamente impossível e relativamente impossível. A absolutamente impossível corresponde a um evento de todo irrealizável; a relativamente impossível envolve um esforço tão absurdo ou a reunião de condições tão extraordinárias que, em termos práticos, equivale a ser impossível ("se fores à lua") ${ }^{141}$. Esta, para todos os efeitos jurídicos, deve ser considerada condição impossível (art. $\left.{ }^{\circ} 271 .{ }^{\circ}, 2\right)$. Com ela não se confunde a condição difícil ou improvável, que não deve ser equiparada a impossível.

139 Nomeadamente aquelas que violem o Regime das Cláusulas Contratuais Gerais.

140 João de Castro Mendes, “Condição necessária...”, 68.

141 João de Castro Mendes, “Condição necessária...”, 76. 


\section{LURDES VARGAS}

Uma condição pode ser objetivamente impossível - impossível para todos - e subjetivamente impossível - apenas impossível para o envolvido na sua realização. Aqui releva o princípio do art. ${ }^{\circ} 791$. $^{\circ}$ Se o evento condicional é fungível é irrelevante a impossibilidade subjetiva; se é infungível a impossibilidade subjetiva equivale à objetiva ${ }^{142}$.

\subsection{IMPOSSIBILIDADE ORIGINÁRIA: O REGIME}

\section{A) Da condição suspensiva}

O regime da impossibilidade originária da condição inicial ou suspensiva implica algumas divisões: entre o regime da impossibilidade da condição de todos os efeitos do contrato e a condição de parte dos efeitos do contrato; e entre contratos onerosos e contratos gratuitos. A primeira justifica-se pela conclusão já assumida de pelo menos o regime do art. ${ }^{\circ} 271 .^{\circ}$ não estar preparado para a condição de efeitos parciais; a segunda divisão é operada pela própria lei.

\section{a) Condição de todos os efeitos do contrato}

\section{Contratos onerosos}

O regime-regra é o da nulidade de todo o negócio ou contrato $\left(271 .^{\circ}, 2\right.$, 1. a parte). Justifica-se pela consideração do contrato condicionado como contrato uno. A condição suspensiva impossível em si é inválida. O contrato condicionado foi querido pelas partes como tal, pelo que a invalidade desse elemento do contrato deve afetar o seu todo. Este é o princípio.

Para alguns, a plenitude desse princípio implica que o contrato condicionado não possa ser reduzido ao abrigo do art. $^{\circ} 292 .^{\circ}$. O regime geral da invalidade é o da irredutibilidade ${ }^{143}$.

142 Ibidem, 76-77. O autor salienta que o art. ${ }^{\circ} 791 .^{\circ}$ não é apenas relevante em termos de conter um regime (no caso de impossibilidade superveniente), mas também em termos de delimitar o conceito de impossibilidade.

143 Pedro Pais de Vasconcelos, Teoria Geral..., 608. 
Não me parece que esta seja a consequência necessária do disposto no art. ${ }^{\circ}$ $271 .^{\circ}$. O art. $^{\circ} 280 .^{\circ}$ também consagra o princípio da nulidade do negócio de objecto contrário à lei, impossível, indeterminável, contrário à ordem pública ou ofensivo dos bons costumes, e articula-se com os regimes do art. ${ }^{\circ}$ $292 .^{\circ}$ e do art. ${ }^{\circ} 293 .^{\circ}$. Nada deve obstar a que o contrato condicionado possa ser reduzido ou convertido, se, por exemplo, apenas parte da condição for impossível ou se for possível obter uma condição equivalente (cf. art. ${ }^{\circ}$ s 292 . $^{\circ}$ e $\left.293 .^{\circ}\right)^{144}$. A redução ou a conversão não transgridem o princípio enunciado, pois, neste caso, a natureza total, una, do negócio condicionado não é de modo algum posta em causa.

\section{Contratos gratuitos}

O regime dos contratos gratuitos é relativamente mais simples, apenas a condição é nula: "considera-se não escrita e não prejudica o (donatário)", excepto declaração do doador em contrário (art. ${ }^{\circ} 2230 .^{\circ}, 1$, ex vi art. $^{\circ}$ $\left.967 . .^{\circ}\right)$

Porquê este regime-regra, por contraposição ao dos contratos onerosos? No testamento o regime poder-se-ia justificar porque seria um modo de salvar o negócio, que não poderia ser repetido ${ }^{145}$. Tal pode ter algum sentido para os testamentos, mas não no que respeita às doações ${ }^{146}$. Não se encontra nenhuma justificação para que as doações condicionais tenham um regime diferente dos contratos onerosos. Sobretudo tratando-se de uma condição suspensiva.

De qualquer modo, assim como se entende relevante a intenção das partes para uma eventual redução do contrato oneroso condicional, também se deve considerar que, perante uma condição impossível aposta numa doação, deve ser apurado se o doador admitiria a produção dos

144 João de Castro Mendes, “Condição necessária...”, 75.

145 Carlos Alberto da Mota Pinto, Teoria Geral..., 570-571. De notar que este regime, mesmo no que respeita ao testamento, não era o do Anteprojeto de Rui de Alarcão: Rui de Alarcão, "Breve motivação do ante-projecto sobre o negócio jurídico na parte relativa ao erro, dolo, coacção, representação, condição e objecto negocial", BMJ, n. ${ }^{\circ} 138$ (1964): 80, artigo 2. ${ }^{\circ}$. Na fundamentação, o autor manifestou discordância relativamente a excepcionar da regra da nulidade as condições suspensivas impossíveis apostas em testamento - 116.

146 José de Oliveira Ascenção, Direito Civil..., II, 355. 


\section{LURDES VARGAS}

efeitos do contrato sem a condição ${ }^{147}$. Entre as condições impossíveis mais ainda do que nas ilícitas, contrárias à ordem pública ou ofensivas dos bons costumes - há situações em que é manifesto que a condição impossível foi aposta como exercício de ironia, manifestando precisamente um intenção inequívoca de não querer.

"Por isso, em toda as hipóteses de mera nulidade da condição, por expressa injunção legal, há que ponderar se as partes terão mesmo querido o negócio sem a condição. Quando for patente a negativa, o facto de a condição se ter «como não escrita» acarreta a nulidade do conjunto." 148

Aliás, “a «declaração em contrário» pode ser tácita nos termos gerais, resultando da declaração negocial no seu conjunto." ${ }^{149}$

\section{b) Condição de parte dos efeitos do contrato}

\section{Contratos onerosos}

$\mathrm{O}$ art. ${ }^{\circ} 271 .^{\circ}$ omite a referência a condições com efeitos totais e condições com efeitos parciais. Porém, como já se discutiu e reconheceu supra, o regime do art. $^{\circ} 271 .^{\circ}$, tal qual, não se adapta à impossibilidade da condição suspensiva que afeta apenas parte dos efeitos do contrato. Quanto à doutrina, mesmo aquela que expressamente admite que a condição pode respeitar a todos ou parte dos efeitos do contrato, não se pronuncia sobre os termos em que o regime do $\operatorname{art}^{\circ} 271 .^{\circ}$ se pode (ou não) aplicar à condição de efeitos parciais.

Uma solução equilibrada será aplicar o regime do art. ${ }^{\circ} 271 .^{\circ}$, com adaptações, nomeadamente conjugado com o art. ${ }^{\circ} 292 .^{\circ}$. Ou seja, sendo a própria obrigação condicionada acessória ou secundária, é de ponderar reduzir o contrato às demais obrigações. Isso, sem prejuízo de analisar se a própria condição pode ser ajustada para ser possível (tratando-se de impossibilidade

147 Neste sentido, Manuel Domingos de Andrade, Teoria..., II, 373; João de Castro Mendes, "Da condição", 57; António Menezes Cordeiro, Tratado..., I, I, 720-721.

148 António Menezes Cordeiro, Tratado..., I, I, 721.

149 Ibidem. 
parcial), também por redução ou conversão (tal como se viu supra quanto à condição suspensiva de efeitos totais impossível).

\section{Contratos gratuitos}

Perante o regime-regra dos contratos gratuitos do art. ${ }^{\circ} 2230 .^{\circ}, 1$, ex vi art. ${ }^{\circ} 967 .^{\circ}$ (supra), não faz muito sentido que se faça qualquer distinção entre condição suspensiva de efeitos totais e de efeitos parciais. E, na verdade, o regime do testamento é claro sobre a sua possível aplicabilidade apenas a parte dos efeitos do negócio, na medida em que refere que "o testador pode sujeitar a instituição de herdeiro ou nomeação de legatário a condição suspensiva ou resolutiva" (art. $.^{\circ} 2229 .^{\circ}$ ).

\section{B) Da condição resolutiva}

Relativamente à condição resolutiva ou final não faz sentido fazer a divisão que se fez quanto à condição suspensiva ou inicial. Perante os regimes-regra consagrados, a divisão entre condição de efeitos totais e condição de efeitos parciais não se justifica. Diretamente ou por analogia, os regimes do art. ${ }^{\circ}$ $271 .^{\circ}, 2,2 .^{a}$ parte, e do $\operatorname{art}^{\circ}{ }^{\circ} 2230 .^{\circ}, 1$ podem ser aplicados à condição de efeitos totais ou à condição de efeitos parciais. Também o tratamento separado da condição impossível em contratos onerosos e em contratos gratuitos não se justifica. $\mathrm{O}$ regime é muito próximo.

A regra para a condição impossível em contratos onerosos é a nulidade da condição - "tem-se a condição por não escrita” ( $\operatorname{art}^{\circ}{ }^{\circ} 271 .^{\circ}, 2,2 .^{a}$ parte). Nos contratos gratuitos a regra é a mesma: "considera-se não escrita e não prejudica o (donatário)". Com a exceção de declaração do doador em contrário (art. ${ }^{\circ}$ 2230. ${ }^{\circ}, 1$, ex vi art. $\left.^{\circ} 967 . .^{\circ}\right)$.

Coloca-se, em primeiro lugar, a questão da diferença de regime face à condição suspensiva impossível. Relativamente à condição suspensiva, justificou-se que o regime-regra fosse o da nulidade total do contrato, em face do caráter unitário do negócio condicionado. Então, não será o contrato sujeito a condição resolutiva também um negócio unitário? Uma justificação, que parece aceitável, é que na condição resolutiva a situação se deve equiparar à não verificação, devendo os efeitos no contrato consolidarem-se como se 


\section{LURDES VARGAS}

nunca tivessem estado dependentes de qualquer evento ${ }^{150}$. Se alguém quis prever - lealmente e sem reserva mental - que um acontecimento poderia extinguir todos os efeitos do contrato celebrado e esse evento era, afinal, desde o início, impossível, então o contrato deve permanecer.

\subsection{IMPOSSIBILIDADE SUPERVENIENTE: O REGIME}

Nesta matéria não há distinção entre contratos onerosos e gratuitos. $\mathrm{O}$ regime dos art. $.^{\circ} 274 .^{\circ}$ e $275 .^{\circ}$, conjugado com o próprio conceito de condição do art. $^{\circ} 270 .^{\circ}$, é unitário. Mas, na minha opinião, já faz muito sentido distinguir os efeitos da impossibilidade da condição suspensiva e os da condição resolutiva. E faz todo o sentido distinguir os casos de impossibilidade da condição total e da condição parcial.

A lei não fala em impossibilidade superveniente. A expressão usada é "não verificação”. Enquanto a condição originariamente impossível é vista como uma não-condição ou condição imprópria, a impossível supervenientemente é uma verdadeira condição que não ocorre.

"Só existe condição impossível no caso da impossibilidade originária; a impossibilidade superveniente é um avatar ou vicissitude da condição verdadeira e própria, sujeita a um regime do artigo $275 .^{\circ}$ e que determina a ineficácia do negócio mesmo no caso de doação e deixas testamentárias." ${ }^{151}$

Em todo o caso, o conceito de impossibilidade faz sentido. Uma condição (evento) que de início era possível deixou do ser, tornou-se inviável. Um conceito equiparado ao da impossibilidade superveniente da prestação nos contratos - art. $^{\circ} 790 .^{\circ}$.

E faz sentido que alguns princípios dos art. ${ }^{\circ}$ s $7900^{\circ}$ ss. se apliquem à impossibilidade superveniente da condição. Assim, faz sentido que a impossibilidade subjetiva das condições não fungíveis seja equiparada à impossibilidade objetiva (art. $\left.{ }^{\circ} 7910^{\circ}\right)$. E também que a impossibilidade temporária, se

150 Carlos Alberto da Mota Pinto, 569-570.

151 João de Castro Mendes, “Condição necessária...”, 78. 
converta em definitiva, quando "atenta a finalidade da condição, se perder o interesse do devedor" (por adaptação do regime do art. ${ }^{\circ} 792 .^{\circ}$ ). E, eventualmente, o regime do art. ${ }^{\circ} 793 .{ }^{\circ}$.

\section{A) Da condição suspensiva}

\section{a) Condição de todos os efeitos do contrato}

Em caso de não verificação da condição suspensiva total, a regra é o negócio não produzir os seus efeitos (decorre do próprio art. ${ }^{\circ} 270 .^{\circ}$ ), com eficácia retroativa plena $\left(274 .^{\circ}\right)$.

E a certeza de que se não pode verificar equivale à não verificação $\left(275 .^{\circ}\right.$, 1). Ou seja, uma situação de impossibilidade superveniente, por ocorrência de qualquer imponderável, é simplesmente equiparada à não verificação.

Ora, este regime pode revelar-se bastante injusto. Parece-me que o resultado da simples e automática aplicação desse princípio extravasa a distribuição do risco contratual pretendida com a condição. Imagine-se que as partes de um contrato acordaram a seguinte condição: “a compra e venda produzirá os seus efeitos na data de chegada do navio $\mathrm{x}$ (que virá buscar o objeto vendido)". Esta condição pode ter sido aposta para benefício do comprador, que está interessado em fazer coincidir o negócio com a chegada de um transporte adequado, mas com data de chegada incerta (por exemplo, porque é o meio de ligação com um destino pouco acessível). Se o navio nunca chegar e naufragar, não faz sentido que o contrato fique sem efeito. Num caso destes, fará sentido aplicar o regime do art. $^{\circ} 793 .^{\circ}$ por analogia, substituindo-se a condição por outra equivalente, mantendo-se o interesse contratual das partes objetivamente considerado (“justificadamente”). Do mesmo modo e por maioria de razão, sendo a própria condição estipulada em parte possível, também deve verificar-se a possibilidade da sua redução, salvando-se o contrato.

Inversamente, a impossibilidade temporária do evento condicional, cuja demora faça que o devedor da obrigação condicionada (o beneficiário da condição) deixe de ter interesse na sua ocorrência, deve resultar em impossibilidade definitiva (art. ${ }^{\circ} 792 .^{\circ}, 2$, por analogia). 


\section{LURDES VARGAS}

No Acórdão do Supremo Tribunal de Justiça, de 8-10-2002 ${ }^{152}$, tratou-se do problema da não verificação de uma condição suspensiva. Tratava-se de uma compra e venda de uma parcela de imóvel, mediante a qual os vendedores, particulares, venderam essa parcela a uma câmara municipal, sob condição de a compradora os autorizar a construir, noutro prédio rústico, prédios nas condições do Plano de Urbanização a aprovar para o local. Não tendo sido contratualmente fixado prazo para se verificar a condição, foi obtida a sua fixação judicial. Nesse prazo a condição não se verificou. O Supremo deu parcialmente razão aos autores-vendedores, considerando não verificada a condição:

"Extinto aquele prazo judicialmente fixado, é esse o momento em que tem de se considerar não verificada a condição por cuja verificação a mesma ré estava obrigada a providenciar, tanto mais que é perfeitamente lógica, à luz de um critério objectivo de razoabilidade, e face ao largo período decorrido desde a escritura, a perda do interesse dos autores na verificação da condição e na eficácia do contrato que a própria propositura desta acção revela, atento que a aludida condição, como ficou assente, foi essencial e determinante para os autores, que de outro modo jamais aceitariam vender a dita parcela pelo valor simbólico que foi o preço praticado (...)"

Ou seja, reconheceu-se que, se não houvesse um prazo limite fixado para verificação da condição, a perda do interesse dos interessados, à luz de critérios objetivos e tendo presente o largo período de tempo, resultaria na não verificação da condição. Ou seja, sem se invocar o art. ${ }^{\circ} 792 .^{\circ}, 2$, considerou-se aplicável o respetivo regime ${ }^{153}$.

Ainda a salientar que o Acórdão considerou relevante a condição ter sido essencial e determinante para os autores, que de outro modo jamais 152 Ac. STJ, de 8-10-2002, P. 02A1011, in www.dgsi.pt.

153 Ac. Rel. Lisboa, de 2-03-2010, P.o 776/07.4TCSNT.L1-1, in www.dgsi.pt. Também referindose a um caso de impossibilidade superveniente da condição suspensiva aposta num contrato-promessa de cessão de quotas e não invocando diretamente o art. $^{\circ} 792 .^{\circ}, 2$, mas considerando: "Também resulta dos factos provados que é impossível a verificação da referida condição suspensiva, não sendo razoável aguardar indefinidamente que as competentes autoridades portuguesas alterem a sua posição devido a uma eventual extensão das certificações obtidas em países da União aos restantes como pretendem os recorridos na contestação." Saliente-se também o interesse do Acórdão noutros aspetos. Por exemplo, a qualificação de condição oferece algumas dúvidas e espaço para uma análise do problema (mais um caso em que condição e dever se podem confundir). 
celebrariam o contrato nas condições acordadas. Este é um critério válido a considerar para se determinar se a impossibilidade superveniente da condição deve determinar a ineficácia do (todo) negócio em causa, ponderando-se a possibilidade da sua redução, com base no art. $^{\circ} 793 .^{\circ}$.

Como consequência da impossibilidade, quando a redução ou conversão não são possíveis, o negócio torna-se totalmente ineficaz: "tudo se passa como se o negócio não tivesse sido concluído, não produzindo consequentemente efeitos, nem ele nem os actos de disposição da parcela porventura praticados na pendência da condição (art. ${ }^{\circ} 274 .^{\circ}$, n. $^{\circ} 1$ do mesmo diploma)." ${ }^{154} \mathrm{~A}$ ineficácia opera retroativamente e é oponível a terceiros.

Por fim, referira-se que o regime-regra é afastado no caso de impossibilidade superveniente provocada ("contra as regras da boa fé") pela parte a quem a impossibilidade aproveita (a quem a condição prejudica) — a condição impedida tem-se por verificada. Assim como a verificação da condição provocada atentatória da boa fé equivale à não verificação $\left(\operatorname{art}^{\circ}{ }^{\circ} 275 .^{\circ}, 2\right)^{155}$.

\section{b) Condição de parte dos efeitos do contrato}

Para a impossibilidade superveniente da condição parcial vale tudo o que se disse acima para a impossibilidade da condição total, entendendo-se o regime dos art. $.^{\circ} 274 .^{\circ}$ e $275 .^{\circ}$ também aplicáveis, diretamente ou por analogia. Mas, fora todos os outros aspetos que se consideraram relevantes para obstar a uma ineficácia total do contrato condicionado, na condição de parte dos efeitos do contrato, naturalmente e como regra, só devem ser afetados os efeitos condicionados, salvando-se o resto do negócio na medida do possível (art. ${ }^{\circ}$ 793. ${ }^{\circ}$, por analogia).

\section{B) Da condição resolutiva}

O regime da condição resolutiva supervenientemente impossível é muito simples. Tem-se por não verificada e o negócio consolida-se, produz definitivamente os seus efeitos ( art. $\left.^{\circ} 275 .^{\circ}, 1\right)$. Apenas assim não sucederá se a sua ocorrência for impedida, contra a boa fé, por quem a impossibilidade

154 Ac. STJ, de 8-10-2002, cit. Na doutrina, Carlos Alberto da Mota Pinto, Teoria Geral..., 569

155 Sobre impossibilidade provocada, contra a boa fé, cf. Ac. STJ, de 8-10-2002, cit., e Ac. Rel. Lisboa, de 10-01-2008, P. ${ }^{\circ}$ 9467/2007-8, in www.dgsi.pt. 


\section{LURDES VARGAS}

aproveita (e a condição prejudica) - considera-se então verificada a condição apesar de impossível $\left(\mathrm{n} .^{\circ} 2\right)^{156}$.

\section{III - Síntese Comparativa}

A comparação desta figura foi uma viagem atribulada. Primeiro era o vazio, nada se sabia. Depois, ao aproximar, as figuras pareciam surpreendentemente semelhantes em dois ordenamentos jurídicos tão diferentes. Entrando-se no tema, tudo pareceu diferente, incomparável. No final, as semelhanças voltam a aparecer, muitas mais do que aquelas que se esperavam.

No common law tudo é mais fluido, mais impreciso, mas, pela própria natureza do modo de criação do direito, os institutos, as figuras jurídicas, são mais flexíveis e adaptam-se com mais facilidade às solicitações dos casos. A condição norte-americana adapta-se a casos muito diferentes e o seu regime também. Imprecisa nos limites, tem um regime de não verificação e impossibilidade mais complexo e completo.

O regime jurídico português da condição é mais preciso, aparentemente mais claro, baseado num corpo de normas legais de âmbito geral. Os contornos da condição são mais precisos. Pelo menos aparentemente. A figura delimita-se perfeitamente de outros institutos do direito civil e do direito das obrigações. Mas o regime jurídico da impossibilidade da condição é mais rígido e perante os casos concretos nem sempre oferece uma resposta clara e justa.

\section{Delimitação da figura e modalidades}

No direito norte-americano a condition do $\$ 224$ do Restatement 2 nd tem contornos aparentemente bem definidos no que respeita ao momento de ocorrência do evento, ao requisito de incerteza, âmbito e efeitos. Afastando a constructive condition, que em princípio está fora do âmbito do presente trabalho por se tratar de condição-dever, a origem contratual também é um ponto

156 Do mesmo modo, também é dada relevância à ocorrência provocada da condição. 
assente. Se confrontarmos a condition do $\$ 224$ com o event that terminates a duty do $\$ 230$ verifica-se uma certa dificuldade em delimitar as duas modalidades, conceptualmente com efeitos bem diferentes, mas confundíveis em certos casos reais. Assim a condition ou condition precedent, formalmente um evento do qual depende o início da produção de efeitos de um contrato, pode ter uma função extintiva dos efeitos de um contrato de execução continuada. Pois ainda se trata de condition sempre que o evento ocorre antes da data de vencimento de cada uma das prestações e, portanto, antes do incumprimento; e só se o evento tiver efeitos extintivos do dever e do respetivo direito de crédito depois da data do vencimento (e eventual incumprimento) é que há uma condition subsequent ou evento do $\$ 230$. Por seu lado, este evento do $\$ 230$ não tem o requisito da incerteza e muitas vezes corresponde ao mero decurso do tempo, como elemento extintivo de um direito de ação.

Seguindo para o direito português e para o regime dos $\operatorname{art}^{\circ}{ }^{\circ} \mathrm{S} 270 .^{\circ}$ ss., a condição suspensiva aproxima-se bastante da condition. Trata-se de fazer depender da ocorrência de um evento, futuro e incerto a ocorrência dos efeitos de um negócio jurídico (para o presente tema, contrato), com base numa estipulação contratual. Mas a condition pode ser bem mais ampla, em face dos efeitos materialmente extintivos que pode produzir. Perante um caso real, o que seria uma condition (precedent) no direito norte-americano, seria uma condição resolutiva no direito português. $\mathrm{O}$ verdadeiro event that terminates a duty é raro, está substancialmente fora do âmbito deste trabalho (sempre que se trate de evento certo) e por isso em pouco coincide com a condição resolutiva - facto futuro e incerto que opera a extinção dos efeitos de um contrato. Na verdade, grande parte das cláusulas que se enquadram no $\$ 230$ do Restatement, transpostas para o ordenamento português, seriam estipulações de caducidade referente ao direito de propor uma ação, nos termos do art. $^{\circ} 330 .^{\circ}$.

Por outro lado, o requisito de incerteza da condition implica que o evento seja futuro, mas claramente pode ser apenas subjetivamente futuro; enquanto no contexto português a maioria da doutrina entende que o evento tem que ser objetivamente futuro para se lhe aplicar diretamente o regime da condição.

As dúvidas nacionais quanto à abrangência da condição não existem no ordenamento norte-americano no que respeita à condition do \$224. Esta 


\section{LURDES VARGAS}

normalmente respeita a parte dos efeitos do contrato, mas também pode respeitar a todos. Já o evento do $\$ 230$ parece estar construído para efeitos totais, embora não seja um seu requisito.

Os eventos condicionais - iniciais ou finais - dos dois ordenamentos podem corresponder a um acontecimento natural, causado por terceiro ou causado pelas partes. Excluindo a condição-dever norte-americana, tanto no direito português, como norte-americano aceita-se que a condição possa corresponder a um acontecimento causado por uma das partes, mais frequentemente pelo credor, mas censura-se e rejeita-se a condição totalmente arbitrária, a qual, se respeitar ao devedor, corresponde a uma falsa vinculação, que impede a formação de um verdadeiro contrato.

Em suma: condition e condição suspensiva são na essência parecidas, mas em pormenor bastante diferentes; o event that terminates a duty só muito vagamente se aproxima da condição resolutiva.

\section{Função e natureza}

A coincidência surpreende. E conforta. Significa que as figuras são na essência comparáveis. Tanto no direito português, como no norte-americano a condição tem como funções principais: a previsão de eventualidades futuras, através da distribuição do risco da sua ocorrência; e, no que respeita a algumas condições, incentivar uma das partes, normalmente o credor, a causar um evento, sem recurso à construção de um dever. Para os norte-americanos estas duas finalidades concentram-se numa mais ampla: proteger o devedor-promitente. O que também se pode reconhecer como fim principal na condição do direito português.

Sem problematizar muito, os norte-americanos consideram a condição como um elemento limitativo ou modificativo de uma promessa. A doutrina nacional discute se a condição é um mero atributo ou modo de ser do contrato ou se é um elemento que se lhe acrescenta. O regime-regra da invalidade total do contrato em caso de condição impossível ou ilícita de algum modo confirma a primeira perspetiva. Concepção próxima da norte-americana. 


\section{POSSIBILIDADE E IMPOSSI BILIDADE ORIGINÁRIA}

Em comum, tratando-se de condição suspensiva e de condition (precedent), um evento impossível, física ou legalmente, não pode servir de condição.

A consequência, no direito norte-americano, é que não há verdadeiramente contrato, o contrato é nulo (null and void). Considera-se que o promitente não se quis verdadeiramente vincular e, se for um contrato bilateral (no sentido de sinalagmático), a sua promessa não pode servir de consideration.

No direito português há uma distinção pouco compreensível. Se o contrato for oneroso, todo o contrato é nulo; se o contrato for gratuito, a condição é nula mas o contrato é válido, excepto declaração contrária do doador (art. ${ }^{\circ} \mathrm{s}$ $271 .^{\circ}, 2$ e 2230. $\left.{ }^{\circ}, 1\right)$. A razão apontada para o regime do contrato oneroso é que as partes, particularmente aquele a quem a condição aproveita, só se quiseram vincular com aquela condição. Se a condição não é possível não é esse o negócio querido. Assim sendo, não se percebe o regime dos contratos gratuitos.

Outra grande e substancial diferença é que no direito português possibilidade-impossibilidade originária é um juízo objetivo. É indiferente que a condição seja possível na convicção das partes. Para o direito norte-americano, possibilidade-impossibilidade originária é aferida subjetivamente, pela convicção do promitente (\$76). Assim, um contrato com efeitos condicionados por acontecimento impossível, que na convicção do obrigado é possível, é válido e vinculante. $\mathrm{O}$ futuro desse contrato será discutido perante o regime da impossibilidade superveniente.

Em comum, os regimes-regra português (art. ${ }^{\circ}$ s $271 .^{\circ}, 2$ e $\left.2230 .^{\circ}, 1\right)$ e norte-americano (\$76) não têm regras específicas para salvar o contrato em caso de impossibilidade originária da condição. Esse efeito pode ser obtido por recurso às regras gerais - no caso português, eventualmente, art. ${ }^{\circ} \mathrm{s} 292 .^{\circ}$ e $293 .^{\circ}$, no norte-americano, os princípios de interpretação e de construction (próximo do que entendemos por integração) dos contratos.

Os regimes da impossibilidade originária do event that terminates a duty e da condição resolutiva são muito parecidos. Se a condição é impossível, ela não tem quaisquer efeitos e as obrigações contratuais tornam-se puras, definitivas - princípio assente na jurisprudência e doutrina norte-americanas e consagrado nos art. ${ }^{\circ}$ s $271 .^{\circ}, 2,2 .^{\text {a }}$ parte, e $2230 .^{\circ}, 1$. 


\section{IMPOSSIBILIDADE SUPERVENIENTE}

Ambos os ordenamentos jurídicos continuam a menorizar o event that terminates a duty e a condição resolutiva. Para ambos, o regime-regra é se o evento não se verifica, seja qual for o motivo, o contrato mantém-se incólume, a produzir os seus normais efeitos. Estes eventos, de efeito extintivo, são tratados como anómalos e indesejados. Se não sucedem é o que se pretende.

Os regimes da condition e da condição suspensiva já são substancialmente diversos.

Para o direito português, o efeito normal da não verificação da condição é a simples não produção dos efeitos do contrato, operando retroativamente (art. ${ }^{\circ} 270 .^{\circ}$, conjugado com o art. ${ }^{\circ} 274 .^{\circ}, 1$ ). E a impossibilidade superveniente propriamente dita é equiparada à simples não verificação $\left(\operatorname{art}^{\circ}{ }^{\circ} 275 .^{\circ}, 1\right)$. Para se evitar os efeitos absolutos da destruição do contrato é preciso recorrer à aplicação analógica das normas do regime da impossibilidade superveniente da prestação. E, manifestamente, o regime da não verificação não pode ser aplicado tal qual à condição parcial. Neste contexto, a jurisprudência dos tribunais superiores tem dado algum contributo para a construção do regime da não verificação da condição suspensiva, recorrendo aos princípios gerais da interpretação dos contratos e à analogia.

O regime norte-americano da impossibilidade superveniente da condition é muito mais sofisticado. Há um leque importante de regras especiais que procuram salvar a própria condição (e, portanto, o contrato), nomeadamente as que integram os $\$ \$ 227$ (1) e 228. E há outras regras especiais, também criação da jurisprudência e consagradas no Restatement 2 nd, $\$ \$ 229$ e 271 , que procuram salvar o contrato não obstante a não verificação da condição. Em termos gerais, uma condition que não seja considerada um elemento substancial de um contrato pode ser afastada se, caso contrário, houver uma perda injustificada (forfeiture) para a o credor do dever condicionado. Perante uma simples não verificação, é necessário forfeiture desproporcionada; perante uma não verificação impedida por acontecimentos extraordinários (impracticability), basta qualquer forfeiture. De notar que o requisito de não ser material para ser afastada não é assim tão difícil de alcançar como aparenta. Desde logo, todos os eventos ainda que incertos que se destinem apenas a fixar o 
momento do cumprimento são por natureza non-material. Depois, condições correspondentes a certificados, peritagens e comprovativos documentais também são genericamente tratadas como non-material, sendo totalmente dispensadas ou substituídas.

Nenhuma destas regras tem paralelo no direito português. E é difícil a sua construção apenas com base em princípios gerais, em face dos art. ${ }^{\circ} \mathrm{s} 270 .^{\circ} \mathrm{ss}$.

\section{NOtA FINAL}

Muitas semelhanças e muitas diferenças. $\mathrm{O}$ direito norte-americano repele pela imprecisão das figuras jurídicas, mas atrai pelo grande bom senso e finura do regime, especialmente no que respeita à impossibilidade superveniente da condição. 
